This is the accepted version of the manuscript.

For citation, please refer to the authoritative final version:

Varet, F., Granié, M.-A., Carnis, L., Martinez, F., Pelé, M., \& Piermattéo, A. (2021). The role of perceived legitimacy in understanding traffic rule compliance: A scoping review. Accident Analysis \& Prevention, 159, 106299. https://doi.org/10.1016/j.aap.2021.106299

(C) 2021. This manuscript version is made available under the CC-BY-NC-ND 4.0 license http://creativecommons.org/licenses/by-nc-nd/4.0/

\title{
The Role of Perceived Legitimacy in Understanding Traffic Rule Compliance: A
}

\section{Scoping Review.}

Varet Florent ${ }^{1}$, Granié Marie-Axelle ${ }^{2}$, Carnis Laurent ${ }^{3}$, Martinez Frédéric ${ }^{4}$, Pelé Marie ${ }^{5}$, Piermattéo Anthony ${ }^{6}$

${ }^{1}$ Corresponding author

Anthropo-Lab, ETHICS EA7446, Lille Catholic University, France

florent-varet@univ-catholille.fr

${ }^{2}$ TS2-LESCOT, Univ Gustave Eiffel, IFSTTAR, Univ Lyon, F-69675 Lyon, France marie-axelle.granie@univ-eiffel.fr

${ }^{3}$ AME-DEST, Univ Gustave Eiffel, IFSTTAR, F-77454 Marne-la-Vallée, France laurent.carnis@univ-eiffel.fr

${ }^{4}$ AME-DCM, Univ Gustave Eiffel, IFSTTAR, Univ Lyon, F-69675 Lyon, France frederic.martinez@univ-eiffel.fr

${ }^{5}$ Anthropo-Lab (ETHICS EA7446), Lille Catholic University, France marie.pele@univ-catholille.fr

${ }^{6}$ PSyCOS-Anthropo-Lab, ETHICS EA7446, Lille Catholic University, France anthony.piermatteo@univ-catholille.fr 


\title{
The Role of Perceived Legitimacy in Understanding Traffic Rule Compliance: A
}

\author{
Scoping Review
}

\begin{abstract}
Background

Perceived legitimacy associated with rules and authorities is an important element for understanding and encouraging compliance with rules in the field of road safety, often more so than with a deterrence approach. Despite a growing interest in legitimacy in recent decades and in the psychological field in particular, its definitions and measurements appear to be heterogeneous, subject to debate and in need of a common theoretical framework. Therefore, one can expect these limitations to also concern the definitions and measurements of legitimacy in the field of road safety. However, no literature review related to this issue is currently available. This contribution therefore aims to fill this void by proposing a scoping review investigating, in the field of road safety, how legitimacy is defined, measured, related to compliance and what are its main determinants.
\end{abstract}

Methods

A scoping review was conducted, based on research literature from eight databases and concerned with the perceived legitimacy of traffic rules or traffic enforcement and rule compliance or traffic violations. Twenty-six publications meeting inclusion criteria were retained. The characteristics and content of publications were analyzed to identify the relevant elements related to our research questions.

Results and conclusion

The main results revealed that perceived legitimacy in the field of road safety can be related to different objects (i.e., traffic rules, traffic violations, traffic enforcement, institutions) that should be better delineated and differentiated in future research. While perceived legitimacy is generally associated with compliance with traffic rules, its theoretical definitions and measures in the field of road safety are heterogeneous and present validity issues which limit the comparability of studies and so the accumulation of knowledge for both theoretical research and road safety applications. No empirical study investigating the outcomes of perceived legitimacy beyond compliance was identified. Few empirical studies have investigated the determinants of perceived legitimacy. Most identified empirical studies were cross-sectional, which is a limitation to establishing causality in investigated relationships. Theoretical implications and research perspectives to improve studies on legitimacy in the field of road safety and develop a multidimensional model of the perceived legitimacy of traffic rules are therefore proposed and discussed.

Key-words: legitimacy; compliance; traffic rules; acceptability; road safety 


\section{Introduction}

Understanding why people comply (or not) with rules is an important issue for social scientists, legal scholars and policy makers. This is particularly the case in the field of road safety where traffic violations are an important factor for explaining the occurrence and severity of serious and fatal accidents (Barraclough et al., 2016; Winter \& Dodou, 2010). These traffic violations usually consist of speeding, drunk-driving or using a mobile phone while driving (Behnood \& Mannering, 2017; ONISR, 2018; Taylor et al., 2000). Despite their legal dimension, some traffic rules such as those related to speed limits are transgressed by a large majority of drivers (Fernández-Dols \& Oceja, 1994; Havârneanu \& Havârneanu, 2012; Lucas \& Pérez, 2003; Pérez et al., 2002). As a result, worldwide, road traffic accidents account for about 1.25 million deaths, representing the 9 th highest cause of mortality, and 20 to 50 million injuries per year. They also represent a substantial economic cost for most countries of almost $3 \%$ of their gross domestic product per year (World Health Organization, 2015). Therefore, understanding factors that explain compliance with traffic rules is an important issue.

Social science research on compliance with rules has notably focused on deterrence approaches and more recently on legitimacy approaches. The deterrence perspective postulates that individuals are motivated to avoid the negative consequences of rule transgressions (when they are aware of them) and that this mechanism is an important trigger for inducing rule compliance (Blumstein et al., 1978; Tittle, 1980; Zimring \& Hawkins, 1973). From this instrumental perspective, people's behaviours are considered as being particularly sensitive to tangible incentives and penalties associated with rule-breaking. Public policies considering this approach as an efficient means of ensuring compliance tend to promote strategies that lead people to perceive undesired behaviours as being extremely risky legally (Harcourt, 2001; Kelling \& Coles, 1996; McArdle \& Erzen, 2001; Sunshine \& Tyler, 2003). Several studies have 
shown that deterrence strategies are effective in controlling crime-related behaviours (e.g., Blumstein et al., 1978; Nagin, 1998) and traffic violations (e.g., Høye, 2014; Kergoat et al., 2017; Stanojević et al., 2013; Walter et al., 2011). Deterrence effects rely on three elements which are certainty, severity and celerity of punishment. Certainty of being caught was found to be more predictive of rule compliance than severity or celerity of punishment for various offences (Decker et al., 1993; Nagin, 2013; Von Hirsch et al., 2000; see Pratt et al., 2006, for a meta-analysis), including traffic violations (e.g., Briscoe, 2004; Homel, 1988; Kergoat et al., 2017).

However, several studies have shown that deterrence effects on compliance can be small and of limited duration (e.g., Bottoms \& Von Hirsch, 2010; Lipsey \& Cullen, 2007; Paternoster, 2010; Wright et al., 2004). Via a meta-analysis, Pratt et al. (2006) found that "the mean sizes of the relationships between crime/deviance and variables specified by deterrence theory are modest to negligible" and that this effect is "much weaker than those found in meta-analyses of the relationships between criminal/deviant behavior and peer effects [...] and self-control" (p. 383). Moreover, because deterrent effects rely on external pressure from the subject, they do not allow self-regulated compliance with rules and require the probability of being punished to be maintained, which is often costly (Tyler, 2006, 2009). Therefore, deterrent strategies appear to be relatively limited in ensuring compliance with rules, although their effectiveness in certain situations cannot be denied, while other social-psychological factors such as perceived legitimacy are also at play and yield important effects for behavioural compliance.

The legitimacy perspective ${ }^{1}$ postulates that individuals voluntarily comply with rules when they perceive them, as well as the authorities and institutions that enforce them, as just, moral,

\footnotetext{
${ }^{1}$ The legitimacy perspective on compliance is concerned with understanding perceived (or subjective) legitimacy, and not with what would be objective legitimacy (Anjuli Van Damme \& Pauwels, 2016). Objective legitimacy could be defined as a characteristic which designates authorities which operate on the basis of certain objective criteria such as absence of corruption (Hinsch, 2010; Hough et al., 2013). Perceived legitimacy could be processed
} 
fair, effective and consistent with their representations of reality and their system of values and beliefs (Kelman, 1961; Tyler, 1990; Yagil, 1998). According to Tyler (1990), people perceive rules as legitimate when they trust the authorities that enforce them and consider that they have the right to make behaviours comply with them. According to Jackson et al. (2012), legitimacy refers to situations where people recognize and justify the power of authorities. From this normative perspective, people are intrinsically motivated to comply with rules when they perceive them, as well as the authorities which dictate them, as legitimate. This mechanism, which relies on self-regulated compliance, does not require the presence of an external pressure and therefore ensures a long-lasting effect (Tyler, 2009). Moreover, legitimacy appears to predict compliance with legal regulations to a greater extent than deterrence factors in several studies (e.g., Hough et al., 2010; Jackson et al., 2012; Sunshine \& Tyler, 2003; Tyler, 2010, 2011; Van Damme, 2013). This effect is also found regarding traffic rules (e.g., Bautista et al., 2015; Van Damme \& Pauwels, 2016). Thus, an intervention from a legitimacy perspective offers an interesting way of increasing compliance with traffic rules as an alternative or a complement to deterrence-based strategies.

Despite a growing interest in legitimacy in recent decades and especially in the psychological field (Jackson, 2018; Tyler, 1990), its definitions and measures appear to be heterogeneous, subject to debate, and in need of a common theoretical framework (Hough et al., 2013; Jackson, 2018; Jackson \& Gau, 2016; Oceja et al., 2001). Objects concerned by legitimacy are not always well differentiated, with some measurements for example confusing the legitimacy of laws with the legitimacy of authorities (Jackson, 2018). Such a phenomenon could serve to limit the ability to define and assess legitimacy appropriately. Therefore, one can also expect these limitations to concern the definitions and measurements of legitimacy in the

independently of objective legitimacy, as authorities that do not meet this criterion can be perceived as legitimate by citizens (Van Damme \& Pauwels, 2016). 
field of road safety. However, no literature review on this issue is currently available. This contribution therefore aims to produce knowledge on this issue through a scoping review (Arksey \& O’Malley, 2005; Munn et al., 2018; Sucharew \& Macaluso, 2019) investigating (a) how legitimacy is defined and (b) measured in the field of road safety; (c) how legitimacy is related to compliance with traffic rules in order to verify its potential interest for road safety issues; (d) what are the main determinants and outcomes of legitimacy (beyond compliance) in the field of road safety, as acting on these variables could be a way to increase perceived legitimacy. A better understanding of legitimacy issues could help in determining the impact of legitimacy in the field of road safety and in increasing compliance with traffic rules and thus prevent road accidents from an applied research perspective.

\section{Methods}

The review was conducted using the method of the scoping review (Arksey \& O'Malley, 2005; Munn et al., 2018). This method is particularly relevant for addressing the way research has been conducted in a particular field (e.g., Reinders et al., 2019; Seidler et al., 2018; van Haperen et al., 2019). Scoping reviews are well suited for purposes such as clarifying key definitions of a concept, identifying key characteristics or factors related to a concept, examining how research is conducted on a certain topic or field, and identifying and analyzing knowledge gaps in the literature. In contrast, the classic systematic review method is rather recommended for addressing a precise question about effectiveness, the appropriateness of an intervention, or relationships between well identified and defined constructs (Munn et al., 2018). In addition, the heterogeneity identified in definitions and measures of perceived legitimacy and similar concepts in the field of road safety did not allow a systematic comparison of statistical relationships to be made nor a meta-analysis as may be presented in classic 
systematic reviews. The five incremental stages proposed by Arskey and O’Malley (2005) for carry out our scoping review are presented and followed below.

\subsection{Identification of the research questions}

As stated by Arksey and O'Malley (2005), this step constitutes the starting point of this scoping review. Given our aim to identify the key elements of definitions, measurement, determinants and outcomes of legitimacy in the field of road safety, we address the following research questions: (a) What are the main theoretical definitions of legitimacy in the field of road safety? (b) What are the main measures proposed to address legitimacy in the field of road safety? (c) Does legitimacy predict compliance in the field of road safety? (d) What are the main determinants and outcomes (beyond compliance) of legitimacy in the field of road safety?

\subsection{Identification of the relevant studies}

\subsubsection{Search Terms}

Key terms in both English and French were selected to identify studies pertinent to the research questions (see Figure 1). On the basis of these questions, a multi-disciplinary team of researchers (i.e., economists, psychologists, with expertise on road safety issues and/or norms and rules concepts) first defined the main categories of keywords which should be used in the search. They also specified the Boolean operators to use among these categories as part of the search. As indicated in Figure 1, these four categories refer to the central investigated concept (i.e., legitimacy), the object to which it applies (i.e., rules), the general field/context of application (i.e., safety), and the behavioural consequences (i.e., behaviour). Each of these keywords served as a basis for providing synonyms, antonyms, and close concepts. These terms were chosen on the basis of the keywords which were collected from a first set of contributions focused on the issue of legitimacy and/or road safety and were used in the search with the Boolean operator "OR". For instance, the term "rule" was not only exchangeable with close 
concepts such as "norms" or "law" but also with keywords related to rule enforcement (e.g., "deterrence", "control"), as this issue is in general a key focus of the application of legitimacy. Finally, as indicated by the asterisks in Figure 1, all the terms were entered in the search in a truncated form in order to allow us to collect references where other forms of these terms, such as the plural form, are used.

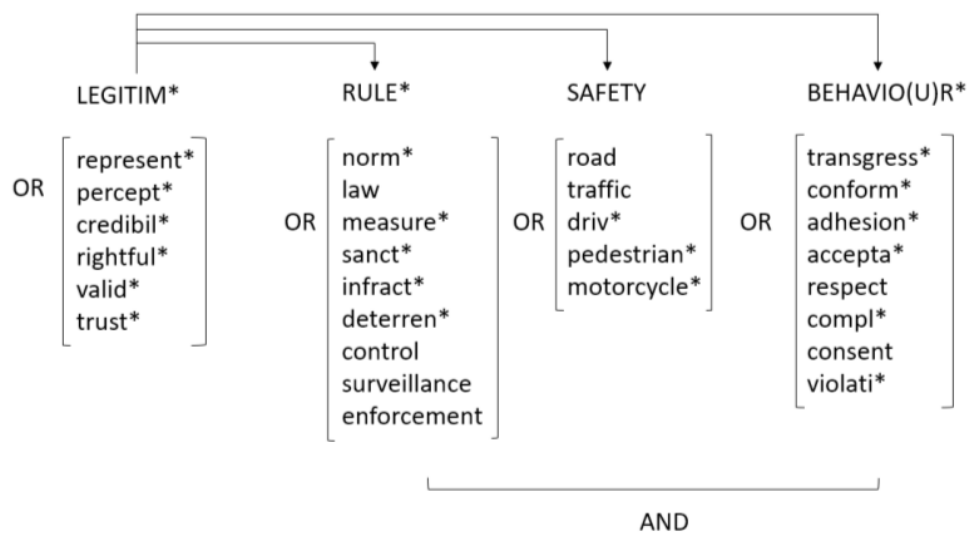

Figure 1. Keywords and Boolean operators used for the search of relevant contributions.

The search was focused on the references which included these keywords in their title and/or abstract and/or own keywords. There was no restriction regarding the type of publications (articles, book chapters, proceedings, etc.), the date or the language. Thus, despite keywords in both French and English, contributions in other languages such as Spanish were also considered.

\subsubsection{Databases}

Nine databases were used (i.e., Academic Search Premier, ERIC, PsycINFO, SAGE, Science Direct, Taylor \& Francis, TRID, Web of Science, Wiley). These databases were chosen on the basis of the combination of two criteria: (1) they had an "advanced search" function, which allowed the search to be conducted according to the requirements we previously mentioned; (2) they included references in the field of social and behavioral sciences or specialized in transportation research. Moreover, most of these databases had been used in 
previous scoping reviews (see for instance Van Haperen et al., 2019). Overall, 3,054 references were found. After a first manual removal of duplicate entries, 2,587 references remained (see Figure 2 for a general presentation of the selection process).

\subsection{Study selection}

Two authors independently classified the 2,587 references into one of the three subsequent categories as follows: (1) publications considered to have a good level of adequacy with the scope ( $n=35)$; (2) publications considered close to the scope, but which did not fully correspond to it and required a more in-depth evaluation ( $n=153)$; (3) publications considered to be out of the scope $(n=2,399)$. On this basis, two other authors evaluated this first classification by giving their opinion on all the publications of the first and the second category and about 103 publications of the third category drawn at random. At this level, the first rate of agreement was $75 \%$. Then, the same two authors discussed the divergent decisions in order to reach an agreement. In consequence, the second agreement rate was $99 \%$. At this stage, the decision for the classification of the last three conflicting publications was made by a third author. This process led to the selection of 46 references. Then, the same multi-disciplinary team of researchers which was assembled to define the search terms, collectively assessed each of these references on the basis of its abstract and a fast general reading of its content. Following this step, 26 references remained. These references were finally distributed among the members of the team for an in-depth reading (two members were chosen for each reference). 




Figure 2. Flow diagram of the reference selection process.

\subsection{Charting the data}

Data of interest from the selected publications were extracted and summarized in Table 1 considering for each publication: authors, year of publication, location of the study, article type (empirical, theoretical), design for empirical studies (qualitative, cross-sectional, quasiexperimental, experimental, longitudinal), sample size and percentage of males, mean age of the sample, origin of the sample (general population, university students, professional drivers), main methodological elements (study design and measures) and main results relevant to this 
review. For each reference, the table was completed by each author who was assigned to read it in depth. For empirical publications, the location was based on the country where the participants were recruited. For theoretical publications, the location was based on the affiliation of the first author. Samples based on participants from different countries were considered in the counting method. For theoretical studies, the location was based on the country of the authors' affiliations.

\subsection{Collating, summarizing and reporting the results}

The results presented in the charting stage were summarized and critically reviewed to determine the extent of identified contributions to the four main research questions. The literature was organized and synthetized thematically in order to identify key elements for (a) defining legitimacy, (b) the main measurements of legitimacy, (c) the main observed relationship between legitimacy and compliance, (d) the main determinants and other outcomes of legitimacy in the field of road safety. The results of the process are presented below.

\section{Results}

In the first part, publication characteristics (publication year, location, article type, study design, sample sizes and sample characteristics) are briefly presented and analyzed. In a second part, we have detailed the identified results successively from each of the four research questions.

\subsection{Publication characteristics}

Article characteristics are summarized in Table 1. All selected references were published between 1988 and 2018. The number of references by year since 1988 ranges from 0 to 4 , increasing over the years, and references published since 2012 represent $58 \%$ of the publications $(n=15)$. Most of the publications are from Europe $(n=16)$, and more particularly 
from Spain $(n=6)$, the United-Kingdom $(n=3)$ and Romania $(n=3)$. Other publications are from Australia $(n=5)$, North America $(n=4)$, South America $(n=3)$ and the Middle East $(n=$ 2). No studies were conducted in Africa, nor in Asia except for Middle Eastern countries (i.e., Turkey and Qatar). Of the 26 selected publications, 24 (92\%) are empirical studies while 2 of them deal with theory and concepts (8\%). Of the empirical references, $12(50 \%)$ are based on cross-sectional design, 8 (33\%) on experimental or quasi-experimental design, 3 on qualitative design (13\%) and 1 on longitudinal design (4\%).

The sample of empirical studies includes 12,954 participants, 54\% of whom are male, $44 \%$ are female, while gender is not specified for $2 \%$ of the total sample. Sample sizes are not detailed for 2 of the studies, and therefore cannot be taken into account. For the 12 crosssectional studies, samples include at least 293 participants, except for one study with $N=75$. The 3 experimental and 5 quasi-experimental studies include at least 123 participants, except for three studies with a sample size ranging from 39 to 72 . For qualitative studies, sample sizes are respectively 228 and 426 in two studies, while this is not specified in the third study. Samples are mostly based on university students for 7 studies, on the general population for 13 studies, and one study on mixed participants from the general population and professional drivers. Across all studies, the unweighted mean age is 37.50 years, ranging from 21 to 51 , and the mean age weighted by study sample sizes ${ }^{2}$ is 43.67 years old.

\footnotetext{
${ }^{2}$ For one study, the sample size was not reported. The mean age for this study was therefore weighted by a factor of 1 .
} 
Table 1.

Characteristics of the selected publications.

\begin{tabular}{|c|c|c|c|c|c|c|c|c|}
\hline References (following alphabetic order) & Location & Article type & Design & $N$ (\%males) & $\begin{array}{l}\text { Mean age } \\
\text { (years old) }\end{array}$ & Sample & Methods & Main results \\
\hline $\begin{array}{l}\text { Alonso, F., Esteban, C., Montoro, L., Useche, S. } \\
\text { A., \& Crowther-Dowey, C. (2017). Knowledge, } \\
\text { perceived effectiveness and qualification of traffic } \\
\text { rules, police supervision, sanctions and justice. } \\
\text { Cogent Social Sciences, 3(1), 1393855. } \\
\text { https://doi.org/10.1080/23311886.2017.1393855 }\end{array}$ & Spain & empirical & cross-sectional & $1100(62 \%)$ & $\mathrm{n} / \mathrm{a}$ & $\mathrm{n} / \mathrm{a}$ & $\begin{array}{l}\text { Secondary data from a self- } \\
\text { administered survey including } \\
\text { measures of perceptions about } \\
\text { traffic rules, traffic violations, } \\
\text { traffic police, sanctions, and justice } \\
\text { functioning. }\end{array}$ & $\begin{array}{l}\text { The majority of drivers perceive } \\
\text { traffic rules as effective but think } \\
\text { that police officers are placed to } \\
\text { catch offenders more than to make } \\
\text { the place safer. Sanctions are } \\
\text { perceived mainly as being either } \\
\text { educational or tax-collections } \\
\text { measures. Drivers evaluate traffic } \\
\text { justice as poorly functioning. }\end{array}$ \\
\hline $\begin{array}{l}\text { Bautista, R., Sitges, E., \& Tirado, S. (2015). } \\
\text { Psychosocial Predictors of Compliance with Speed } \\
\text { Limits and Alcohol Limits by Spanish Drivers: } \\
\text { Modeling Compliance of Traffic Rules. Laws, 4(3), } \\
\text { 602-616. https://doi.org/10.3390/laws4030602 }\end{array}$ & Spain & empirical & cross-sectional & $570(53 \%)$ & 44.23 & $\begin{array}{c}\text { general } \\
\text { population }\end{array}$ & $\begin{array}{l}\text { Telephone survey measuring } \\
\text { compliance with traffic rules, } \\
\text { deterrence variables, social norms } \\
\text { about traffic violations and } \\
\text { perceived morality of traffic rules. }\end{array}$ & $\begin{array}{l}\text { Compliance with traffic rules is not } \\
\text { predicted by the perception of the } \\
\text { severity in case of violation but is } \\
\text { mainly predicted by the descriptive } \\
\text { norm of the reference group and by } \\
\text { the perceived morality of traffic } \\
\text { rules. }\end{array}$ \\
\hline $\begin{array}{l}\text { Bradford, B., Hohl, K., Jackson, J., \& MacQueen, } \\
\text { S. (2015). Obeying the Rules of the Road } \\
\text { Procedural Justice, Social Identity, and Normative } \\
\text { Compliance. Journal of Contemporary Criminal } \\
\text { Justice, 31(2), 171-191. } \\
\text { https://doi.org/10.1177/1043986214568833 }\end{array}$ & UK & empirical & $\begin{array}{c}\text { quasi- } \\
\text { experimental }\end{array}$ & $816(63 \%)$ & 50.7 & $\begin{array}{c}\text { general } \\
\text { population }\end{array}$ & $\begin{array}{l}\text { Drivers were stopped by police } \\
\text { officers using either a routine } \\
\text { approach (control group) or an } \\
\text { approach based on the procedural } \\
\text { justice model (treatment group). } \\
\text { Drivers completed a self- } \\
\text { administered survey including } \\
\text { future traffic compliance, } \\
\text { perception about road traffic stop } \\
\text { procedural justice, police legitimacy } \\
\text { and effectiveness, risk of sanction, } \\
\text { personal morality and social } \\
\text { identity. }\end{array}$ & $\begin{array}{l}\text { Experienced procedural justice with } \\
\text { police increases future traffic } \\
\text { compliance and social identification } \\
\text { with law-abiding citizen. Social } \\
\text { identification - and not legitimacy - } \\
\text { explain the effect of procedural } \\
\text { justice on compliance. Both } \\
\text { instrumental and normative factors } \\
\text { predict future traffic compliance. }\end{array}$ \\
\hline $\begin{array}{l}\text { Chermak, S., McGarrell, E. F., \& Weiss, A. (2001). } \\
\text { Citizens' perceptions of aggressive traffic } \\
\text { enforcement strategies. Justice Quarterly, 18(2), } \\
\text { 365-391. } \\
\text { https://doi.org/10.1080/07418820100094941 }\end{array}$ & USA & empirical & $\begin{array}{c}\text { quasi- } \\
\text { experimental }\end{array}$ & $420(32 \%)$ & 51 & $\begin{array}{c}\text { general } \\
\text { population }\end{array}$ & $\begin{array}{l}\text { Two type of aggressive traffic } \\
\text { enforcement were implemented in } \\
\text { two areas in comparison with a } \\
\text { control area. A pre and post- } \\
\text { intervention telephone survey was } \\
\text { proposed to residents in the three } \\
\text { area, measuring perceptions about } \\
\text { police practices, crimes and quality } \\
\text { of life. }\end{array}$ & $\begin{array}{l}\text { In overall, implemented aggressive } \\
\text { traffic enforcements are strongly } \\
\text { supported by the residents and not } \\
\text { perceived as harassment. However, } \\
\text { residents in the experimental areas } \\
\text { did not perceived a decrease in } \\
\text { crime nor an increase in quality of } \\
\text { life. }\end{array}$ \\
\hline $\begin{array}{l}\text { Debnath, A. K., Haworth, N., \& Rakotonirainy, A. } \\
\text { (2017). Driver beliefs regarding the benefits of } \\
\text { reduced speeds. Journal of Transportation Safety \& }\end{array}$ & Australia & empirical & cross-sectional & $3538(50 \%)$ & 46.3 & $\begin{array}{c}\text { general } \\
\text { population }\end{array}$ & $\begin{array}{l}\text { Self-administered online survey } \\
\text { measuring variables related to } \\
\text { perceived benefits of reducing }\end{array}$ & $\begin{array}{l}\text { Drivers under the age of } 29 \text { years } \\
\text { perceive less benefits of reducing } \\
\text { speed on emissions, stress and road }\end{array}$ \\
\hline
\end{tabular}


Security, 9(4), 470-488

https://doi.org/10.1080/19439962.2016.1241848

Demir, M., Apel, R., Braga, A. A., Brunson, R. K., \& Ariel, B. (2020). Body Worn Cameras,

Procedural Justice, and Police Legitimacy: A
Controlled Experimental Evaluation of Traffic

Stops. Justice Quarterly, 37(1), 53-84.

https://doi.org/10.1080/07418825.2018.1495751

Elvik, R. (2006). Are individual preferences always a legitimate basis for evaluating the costs and

benefits of public policy? Transport Policy, 13(5),

379-385.

https://doi.org/10.1016/j.tranpol.2006.01.002

Fernández-Dols, J. M., \& Oceja, L. V. (1994).

Fectos cotid, J. M., \& Oceja, L. V. (1994).

tolerancia a la corrupción. Revista de Psicología

Social, $9(1), 3-12$

https://doi.org/10.1174/021347494763591762

Gau, J. M. (2012). Consent Searches as a Threat to Procedural Justice and Police Legitimacy: An Analysis of Consent Requests During Traffic Stops. Criminal Justice Policy Review, 24(6), 759-777.

https://doi.org/10.1177/0887403412464547

Gaymard, S. (2009). Norms in social representations: Two studies with French young drivers. European Journal of Psychology Applied to Legal Context, 1(2), 165-181.
Turkey

empirical$$
\text { quas - }
$$$$
\text { experimenta }
$$

$624(96 \%)$

40.76

Norway

theoretical $n / a$
Drivers were stopped by police officers with a body worn came (treatment group) or withour (control group). Drivers completed a survey measuring variables rela to perceived procedural justice, general police legiti

Different types of traffic police interventions were analyzed and economical perspective.

Self-administered survey proposed to drivers and non-drivers presenting a vignette where someone allow a person to escape a fine due to speeding (very comm transgression) or drinking and driving (less frequent transgression). The dependent

rage than the older drivers. Female, drivers of small cars, drivers of automatic car and bicycle cons on safety, stress

Drivers in the treatment group report a greater perception of procedural justice, general police legitimacy than drivers ince control group.

The cost-benefice ratio for differen type of traffic police enforcements is less advantageous when benefits obtained from driving violations included in analyses. Including benefits from driving violations can

be considered as a legitimate

Participant were more tolerant of the situation involving speeding than drinking and driving. Driver were more tolerant of the situation iniving

general Secondary data from a survey including measures of perception about perceived procedural justice stops by police officers.

Self-administered survey with manipulation of the instructions, including measures of traffic violations and their personal acceptability in different situations.
Perceived procedural justice and legitimacy of previous traffic stop are lower when police officers conducted a consentsey of the vehicle than when they did not.

Driving violations and their situation, and traffic rules can therefore be conditional. Speed limits are the most conditional traffic rules. Traffic violations can be normative. acceptability depend of the driving 
Havârneanu, M. G., \& Havârneanu, C. E. (2012). When norms turn perverse: Contextual irrational vs. rational traffic violations. Transportatio Research Part F: Traffic Psychology and Behaviour, 15(2), 144-151

https://doi.org/10.1016/j.trf.2011.12.003

Havârneanu, M. G., \& Goliță, A. (2010). Traffic norms between safety and perversity. Annals of the "Al. I. Cuza" University, Psychology series, 19(1),

Holman, A. C., \& Popusoi, S. A. (2018). Avoiding blame when violating traffic rules: The

development and validation of the justifications of traffic violations scale. Psychology. Crime \& Law, 24(9), 873-894

https://doi.org/10.1080/1068316X.2018.1442450

Lacalle, M. a E., \& Oceja, L. V. (1996). Efectos perversos de normas incumplidas en la percepció de las autoridades. Revista de Psicología Social. ll(1),83-91.

https://doi.org/10.1174/021347496763336637

Lanza-Kaduce, L. (1988). Perceptual deterrence and drinking and driving among college students. Criminology, 26(2), 321-341.

https://doi.org/10.1111/j.174

9125.1988.tb00844.x

MacQueen, S., \& Bradford, B. (2015). Enhancing public trust and police legitimacy during road traffic encounters: Results from a randomised controlled trial in Scotland. Journal of

Experimental Criminology, 11(3), 419-443. https://doi.org/10.1007/s1 1292-015-9240-0
Self-administered survey including measures of violations in perverse situations, perceived irrationality of traffic rules, perceived risk in respect for the law.

Romania cross-sectional

drivers

Romania

empirical

cross-sectional

study 1: $382(50 \%)$ $325(48 \%)$

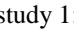
39.27
study 2 39.06

general population specific perverse situations, perceived irrationality of traffic rules, experience with police and
traffic violation justifications.

Interviews and self-administered survey used to create and validate the justifications of traffic violation scale. Measures also include driving styles, traffic violations and accidents.

\section{iversity}

Self-administered survey proposed to drivers and non-drivers presenting a vignette where someone allow a person to escape a fine due to three different traf violations. Measures include tolerance of the situation, the amount of the fine considered as being able to the likelihood of

Longitudinal self-administered survey including measures of recen and past drinking and driving, prior perceived risk of punishment, mora for drinking and driving.

Drivers were stopped by police population approach (control group) or an approach based on the procedura justice model (treatment group). Participants completed a pre and post intervention self-administered survey including measures of trust officers who made the stop, trust
Perceived irrationality of traffic rules, low risk perception, little respect for the law and frequent wial deviant behaviour are violations.

Previous accident involvement, negative experience with police an fear of police control are linked with more frequent traffic violations.

Traffic violations are mostly justified through four types of strategies. The use of each of these justifications is positively associated with maladaptive driving styles, traffic violations and accidents.

Participant are more tolerant, advocate a lower fine and estimate a greater likelihood of being able to involving for the situation involving the most usual traffic
violations. Drivers are more toleran of the three situations than nondrivers.

Subsequent drinking and driving are predicted by prior moral tolerance, past drinking and driving and previous legal intervention, but not by prior perceptions of risk of arrest

The results are opposed to the authors' hypothesis: In the treatment group, the intervention made the stop and satisfaction with their conduct and did not have significant effect on trust in the police nor police legitimacy. 
McKenna, F. P. (2007). The perceived legitimacy of intervention: A key feature for road safety. Improving traffic safety culture in the United States: The journey forward. Washington, $D C$ : AAA Foundation for Traffic Safety, 165-175.

Musselwhite, C., Avineri, E., \& Susilo, Y. O. (2014). Legitimising risk taking: Articulating dangerous behaviour on the road. Transportation Planning and Technology, 37(1), 62-82.

https://doi.org/10.1080/03081060.2013.844905

Oceja, L. V., Fernández-Dols, J. M., González, A., Jiménez, I., \& Berenguer, J. (2001). ¿Por qué cumplimos las normas? Un análisis psicosocial del concepto de legitimidad. Revista de Psicología Social, 16(1), 21-41.

https//doi org/101174/021347401317351189

Pechansky, F., Chandran, A., \& Sousa, T. (2016). Bridging a historical gap: Can changes in

perceptions of law enforcement and social

deterrence accelerate the prevention of drunk

driving in low and middle-income countries?

Revista Brasileira de Psiquiatria, 38(2), 161-166.

https://doi.org/10.1590/1516-4446-2015-1878

Pérez, J. A., Lucas, A., Dasi, F., \& Quiamzade, A. (2002). La desobediencia masiva al código de

. Lión Normas heteróno inter-individuales. Psicothema, 14(4), 788-794. police.

Principles guiding interventions to reduce road accidents are discussed with consideration for philosophical arguments and psychological

processes, with special attention to perceived legitimacy and the harm principle.

Six focus groups met three times, exploring social and environmental factors linked with risky driving an traffic violations. Responses were analyzed through the theory of planned behaviour and the ecological system theory.

Self-administered survey including measure of conventionalism, compliance with different rules (including traffic rules), perceive likelihood of being arrested or sanctioned, social disapprobation and legitimacy associated with rule violations.

Brazil,

empirical

qualitative

n/a

Semi-structured interviews with road safety professionals from six country with different levels of driving while under the influence of alcohol/drugs (DWI) rates, based on a case vignette.

Self-administered Spanish survey proposed to drivers and non-drivers, where Spanish drivers were presented as those who commit th most (violation condition) or the least (compliance condition) Mesures of effectivetions. to prevent traffic accients viontions, prefercice for he type sanction and tolerance for traffic

The perceived legitimacy of speeding could be reduced by emphasizing the consequences for potential victims. Education and improving trust in authorities should be used to reduce the perceived legitimacy of speeding and increase the perceived legitimacy of speed limits.

Drivers can be aware and critical of many of the determinants of their risky behaviours. Their explanation of their risky behaviours allow them to legitimize them. Younger drivers are more influenced by the symbolic role of the car.

The perceived legitimacy of rule violations is negatively associated with rules compliance and is its only significant predictor. This association is stronger among individuals with a high (vs. low) level of conventionalism.

The most successful countries in reducing DWI rate seem to be those where DWI is most socially

perceived as deviant. Generating a social stigma against DWI allows legislation to be enforced.

Drivers perceive fine as being more effective in the violation condition than in the compliance condition. This pattern is reversed for no drivers. Drivers express more tolerance for traffic violations tha condition, while this paten condition, while this pattern is condition. 
Prat, F., Gras, M. E., Planes, M., Font-Mayolas, S., \& Sullman, M. J. M. (2017). Driving distractions: An insight gained from roadside interviews on the prevalence and factors associated with driver distraction. Transportation Research Part F: Traffic Psychology and Behaviour, 45, 194-207. https://doi.org/10.1016/j.trf.2016.12.001

Shaaban, K. (2017). Assessment of Drivers' Perceptions of Various Police Enforcement Strategies and Associated Penalties and Rewards. Journal of Advanced Transportation, 2017, 1-14. https://doi.org/10.1155/2017/5169176

Verkuyten, M., Rood-Pijpers, E., Elffers, H., \& Hessing, D. J. (1994). Rules for Breaking Formal Rules : Social Representations and Everyday RuleGoverned Behavior. The Journal of Psychology, 128(5), 485-497.

https://doi.org/10.1080/00223980.1994.9914908

Watling, C. N. (2018). Drivers' perceived legitimacy of enforcement practices for sleeprelated crashes: What are the associated factors? Journal of Forensic and Legal Medicine, 54 34-38. https://doi.org/10.1016/j.jflm.2017.12.005

Watling, C. N., \& Leal, N. (2012). Exploring perceived legitimacy of traffic law enforcement Proceedings of the 2012 Australasian College of Road Safety National Conference, 1-13. survey proposed to drivers, measuring perceptions a opinions about acceptability and effectiveness of different existing or proposed police traffic enforcement strategies and associated penalties and rewards.

Self-administered survey including measures of representations about rules and situations where it is justifiable to transgress them and acceptability of violations in

Australia

empirical

cross-sectional

293(41\%)

Australia

empirical

coss-section $293(41 \%)$ different situation.

general populatio

Self-administered survey proposed to drivers, including measures of perceived legitimacy of

enforcement and attitude toward sleepy driving, personality and risktaking factors.

general

population to drivers, including measures of athucs toward dinterent trafic traffic law enforcement strategies and future traffic violations.
Drivers are well aware of the distractive and risky aspects of secondary activities while driving. They have acculate knowledge of other than phone use.

Among the existing strategies, redlight running cameras are perceived as being the most effective existing strategy, particularly because of the high fine associated, while the

system demerit point is perceived as being the less effective. Among the proposed strategies, rewarding safe drivers is perceived as the more effective.

Participants provide consensual and convergent responses on the reason for not complying with certain rules such as stopping at red lights, suggesting the existence of shared representations about rule

Perceived legitimacy of enforcement of sleepy driving is toward sleepy driving, extraversion, and positively associated with age.

Perceived legitimacy of traffic law enforcement is negatively linked
with attitudes towards traffic violation and is positively linked with future traffic violations. Attitude towards traffic violations is positively linked with future traffic positively ling 


\subsection{Results associated with research questions}

\subsubsection{What are the main theoretical definitions of legitimacy in the field of road safety?}

The thematic analysis of selected publications shows that legitimacy can refer to different objects at different levels of analysis from traffic rules to institutions that make these laws. Moreover, several definitions of legitimacy refer to existing psychological concepts. These elements are presented and summarized in Table 2. Thus, legitimacy can refer to specific traffic rules such as speed limits and alcohol limits (e.g., Bautista et al., 2015; Oceja et al., 2001). Some studies have also investigated the legitimacy that individuals associate with traffic rules in general (e.g., Alonso et al., 2017). It appears from the selected publications that legitimacy could also apply to traffic violations. For example, McKenna (2007) addressed the legitimacy of speeding referring to how people perceived speeding as acceptable. Bautista et al. (2015) addressed the legitimacy of speeding and drunk driving, measuring how bad these behaviours are perceived to be. Legitimacy was also frequently considered from the point of view of law enforcement authorities (i.e., police officers and the police organization more broadly) and referred in particular to the process by which they decide to impose penalties or interact with the road user. From this perspective, these behaviours are often associated with trustiness, and legitimacy thus refers to procedural justice (e.g., Bradford et al., 2015; Chermak et al., 2001; MacQueen \& Bradford, 2015). Penalties can be another issue related to legitimacy, distinct from the way in which they are imposed, which is often associated with fairness and refers to distributive justice (e.g., Demir et al., 2018; Watling, 2018; Watling \& Leal, 2012). Finally, legitimacy can refer more broadly to legal institutions (e.g., Bradford et al., 2015) or to a system of rules (e.g., Bautista et al., 2015). 
Table 2

Main definitions of legitimacy in the field of road safety as linked with other concepts

\begin{tabular}{|c|c|c|}
\hline $\begin{array}{l}\text { Main concepts used to define } \\
\text { legitimacy }\end{array}$ & References & Usual definition of the concepts \\
\hline $\begin{array}{l}\text { Legitimacy as perceived } \\
\text { rationality, effectiveness or } \\
\text { appropriateness }\end{array}$ & $\begin{array}{l}\text { Bautista et al. (2015); } \\
\text { Havârneanu \& Goliță (2010); } \\
\text { Havârneanu \& Havârneanu } \\
\text { (2012) }\end{array}$ & $\begin{array}{l}\text { Perceived rationality, effectiveness or appropriateness refers to the appreciation that } \\
\text { an object such as a rule is well adapted to a given purpose and in a given context. }\end{array}$ \\
\hline Legitimacy as acceptability & $\begin{array}{l}\text { McKenna (2007); Shaaban } \\
\text { (2017); Watling \& Leal (2012) }\end{array}$ & $\begin{array}{l}\text { Acceptability refers to a judgment in terms of agreement or approval towards an } \\
\text { object such as a rule, a penalty or a rule-violation. }\end{array}$ \\
\hline Legitimacy as moral judgement & $\begin{array}{l}\text { Bautista et al. (2015); Bradford } \\
\text { et al. (2015); Oceja et al. (2001) }\end{array}$ & $\begin{array}{l}\text { Moral judgment refers to how badly people perceive an object or a behaviour such } \\
\text { as a rule, a penalty or a rule-violation. }\end{array}$ \\
\hline Legitimacy as moral alignment & $\begin{array}{l}\text { Bradford et al. (2015); } \\
\text { MacQueen \& Bradford (2015) }\end{array}$ & $\begin{array}{l}\text { Moral alignment refers to the degree of congruence between the values of the } \\
\text { individual and the values they ascribe to an object such as a rule or an authority. }\end{array}$ \\
\hline Legitimacy as obligation to obey & $\begin{array}{l}\text { Bautista et al. (2015); Bradford } \\
\text { et al. (2015); MacQueen \& } \\
\text { Bradford (2015) }\end{array}$ & $\begin{array}{l}\text { Obligation to obey refers to the internalized sense of duty to obey the law or the } \\
\text { directive of the legal authority }\end{array}$ \\
\hline $\begin{array}{l}\text { Legitimacy as procedural justice } \\
\text { or trustiness }\end{array}$ & $\begin{array}{l}\text { Bradford et al. (2015); Chermak } \\
\text { et al. (2001); MacQueen \& } \\
\text { Bradford (2015) }\end{array}$ & $\begin{array}{l}\text { Procedural justice or trustiness refers to how people perceive the judiciary process } \\
\text { by which an agent makes decisions and produces outcomes, in terms of fairness, } \\
\text { equality, neutrality, rationality, dignity, respect and transparency. }\end{array}$ \\
\hline $\begin{array}{l}\text { Legitimacy as distributive justice } \\
\text { or fairness }\end{array}$ & $\begin{array}{l}\text { Demir et al. (2018); Watling } \\
\text { (2018); Watling \& Leal (2012) }\end{array}$ & $\begin{array}{l}\text { Distributive justice or fairness refers to how people perceive the allocation of } \\
\text { outcomes, resources, to be fairly distributed across individuals and/or social groups. }\end{array}$ \\
\hline
\end{tabular}


Throughout the selected publications, definitions of legitimacy often rely on procedural and distributive justice, but also on fairness, trustiness and appropriateness. These elements are presented either as concepts distinct from legitimacy, as one of its determinants or outcomes, or as concepts overlapping legitimacy, therefore including procedural and distributive justice dimensions as potential components of legitimacy.

Legitimacy also appears to be often defined through two aspects that are linked to a personal sense of morality and values. Regarding moral judgment, legitimacy refers to what extent the rules (or on the contrary their transgressions) are judged to be right or wrong (Bautista et al., 2015; Bradford et al., 2015; Oceja et al., 2001). Regarding moral alignment, legitimacy is defined as a congruence between the values of the road user and the values ascribed to the rules. A strong congruence between personal values and ascribed values is associated with a high perceived level of legitimacy. This mechanism leads to a process of internalization and legitimation of the rules (Havârneanu \& Goliţă, 2010; Tyler, 1990; Yagil, 1998). The second aspect of legitimacy, obligation to obey, is defined as "a belief that the legal authorities have a legitimate right to dictate behavior" (Havârneanu \& Goliţă, 2010, p. 67; see also Bautista et al., 2015; Bradford et al., 2015). In other words, there is a perceived legitimacy related to the authorities enforcing the law (Tyler, 1990). Moral alignment and the sense of obligation to obey can be considered as being two distinct yet related components of legitimacy (Bradford et al., 2015; Hough et al., 2013; Jackson, Bradford, Hough, et al., 2012). Oceja et al. (2001) argue that the obligation to obey would refer to a conventionalist orientation, a tendency to comply blindly with authorities, without any evaluation of the consequences of their injunctions. Less frequently, legitimacy of rules also appears to be defined through the concepts of acceptability. However, no explicit definition of acceptability is proposed in the three publications that refer to acceptability in relation to legitimacy (McKenna, 2007; Shaaban, 2017; Watling \& Leal, 2012). Finally, legitimacy also appears to be defined through the perceived rationality of traffic 
rules, which refers to their perceived effectiveness in preventing accidents, or their appropriateness for the needs of real traffic safety situations (e.g., Bautista et al., 2015; Havârneanu \& Goliţă, 2010; Havârneanu \& Havârneanu, 2012).

\subsubsection{What are the main measures proposed to address legitimacy in the field of road safety?}

We identified measures associated with legitimacy in 14 empirical studies of our review. In the other empirical studies of our review, legitimacy or closely related concepts are mobilized theoretically but are not measured. Identified measures were grouped according to the object of legitimacy to which they related and to the concept used to operationalize the legitimacy (see Table 3). Thus, legitimacy measures are proposed for the following objects: (a) traffic rules, (b) traffic violations, (c) police, (d) sanctions and means of control, (e) general law, legal institutions, or legal system. On a general level, one should note that, in most of the studies, no elements of internal consistency and construct dimensionality were reported. Also, in some studies, no details were given about the content of the items used. Regarding the number of items for each measure, this ranges from a single item measure to 31 items. This gap in the number of items used can be observed for the same concept (see for instance in Table 3 the example of measures related to perceived rationality, appropriateness or efficiency of specific traffic rules).

While measures focus on different objects of legitimacy, we also note that for each object, several concepts can be mobilized in order to operationalize legitimacy. Thus, the legitimacy of traffic rules is assessed through different characteristics such as perceived rationality (i.e., the perception of the adaptation of rules to real safety needs), appropriateness, or efficiency (Bautista et al., 2015; Havârneanu \& Goliţă, 2010; Havârneanu \& Havârneanu, 2012), perceived general effectiveness, or perception as fair/unfair, adequate, excessive/sparse, and well/poorly done (Alonso et al., 2017). Depending on the contribution, these measures could be related to a general perception of traffic rules (Alonso et al., 2017) or focused on 
specific rules such as speed and alcohol limits (Bautista et al., 2015; Havârneanu \& Goliţă, 2010; Havârneanu \& Havârneanu, 2012). In the case of Havârneanu and Goliţă (2010) these specific rules were distinguished on the basis of the concept of perverse norms (i.e., rules that imply punishment in the case of violation but which are violated by the majority of drivers). However, in the case of measures focused on specific rules, while items could be treated in distinct analyses, they also could be computed in a mean score which presents an acceptable reliability ( $\alpha=.72$; Havârneanu \& Havârneanu, 2012).

The legitimacy of traffic violations is mainly assessed through measures based on a moral judgement associated with specific traffic violations (Bautista et al., 2015; Bradford et al., 2015; Oceja et al., 2001). Participants were generally asked to evaluate how wrong some traffic violations were (e.g., drunk driving, breaking the speed limit, running a red light). Alonso et al. (2017), adopted a different approach and focused on the perceived dangerousness and perceived seriousness of different traffic violations.

Measures of the legitimacy of the police or legal authorities appear to be the most frequent and heterogeneous measures of legitimacy in the field of road safety and mainly focus on the police. We note that in some cases, the same criteria as for the legitimacy of laws or traffic violations were used. Thus, police legitimacy has been assessed through moral alignment with the police, relying on the perception that the police operate in accordance with the respondent's conception of what is right and wrong (Bradford et al., 2015; MacQueen \& Bradford, 2015). In the same way as traffic rules, police legitimacy was also assessed through a criterion of effectiveness (Bradford et al., 2015; Chermak et al., 2001; MacQueen \& Bradford, 2015). These measures assess trust in the effectiveness of the police in a general way (Bradford et al., 2015), regarding traffic issues (MacQueen \& Bradford, 2015) or at neighborhood level (Chermack et al., 2001). Two of these studies also used a measure of obligation to obey the police (Bradford et al., 2015; MacQueen \& Bradford, 2015), adapted from the commonly used 
obligation to obey scale (Tyler, 1990). Police legitimacy was also measured through various characteristics attributed to the police, mainly on the basis of past experience of encounters with police officers. Depending on the contributions, participants could be asked if the past experience they had with traffic police was either positive or negative (Havârneanu \& Goliţă, 2010), if the police officer was perceived as behaving properly and respectfully (Gau, 2012), or they could be asked about the perceived professionalism and courteousness of the police officer encountered (Chermak et al., 2001). While most of these measures consist of a few items focused on specific aspects, Demir et al. (2018) proposed a multidimensional scale addressing perceived police legitimacy at different levels. The authors proposed a three-factor model tested with a confirmatory principal component factor analysis. The first factor "procedural justice perception" taps into different perceptions of a police encounter (e.g., perceived politeness, fairness, capacity to base decision on rules and listening to the respondent for the officer) and shows a good reliability $(\alpha=.87)$. The second and third factors referred to "traffic police legitimacy perception" and "general police legitimacy perception", tapping into feelings of respect, confidence and trust from the respondent toward the police officers and show a good reliability (respectively $\alpha=.86$ and .89 ). However, fit indices of the confirmatory analysis were not reported and the authors mentioned that an exploratory principal component analysis suggested a unidimensional solution.

As for most of the other objects of legitimacy, the legitimacy of traffic rule enforcement and penalties was also assessed through a criterion of effectiveness. More precisely, Pérez et al. (2002) measured the perceived effectiveness of fines in preventing road accidents with one item ("Do you think that police fines are a good remedy for traffic accidents?"). The other measures either focus on a broad assessment (Alonso et al., 2017) or on specific traffic rules (Watling \& Leal, 2012). In Alonso et al. (2017) participants were asked about their degree of agreement with three purposes that may be associated with traffic rules ("the purpose of the 
punishment is essentially tax collection", "the purpose of the punishment is primarily educational" and "the purpose of the penalty is fundamentally punitive."). In Watling and Leal (2012), the perceived legitimacy of enforcement was based on several items for each violation which were drunk driving, speeding, fatigued driving and driving without a seatbelt. For each traffic rule, participants were asked to evaluate the legitimacy of different means of control (e.g., randomly stopping drivers to check seatbelt use) or penalties (e.g., charging crashinvolved drivers who were not wearing a seatbelt).

Finally, at a wider level, measures of legitimacy associated with the law in general, legal institutions, the state and the legal system were investigated by some contributions. Here again, a criterion of effectiveness has been mobilized in order to assess the functioning of the justice system (both in an overall way or in the specific field of road safety; Alonso et al., 2017) or within the framework of the social conformism measure proposed by Havârneanu and Havârneanu (2012). This scale consists of two subscales that are respect for the law and social order acceptance which respectively tap into perceived effectiveness and the rationality of state institutions (e.g., "The law might be harsh but it must be obeyed because it is a law") and attitudes toward the effectiveness and rationality of law and governmental institutions (e.g., "State institutions are rationally organized and very well-functioning"). However, both of these subscales present a poor reliability (respectively $\alpha=.47$ and $\alpha=.50$ ). Beyond effectiveness, the perceived legitimacy of the law and legal authorities was also assessed through Tyler's obligation to obey scale (Bautista et al., 2015). This version of the scale included items related to obeying the law and authorities, and presented an acceptable reliability $(\alpha=.67)$. 
Table 3.

Main measures used to address legitimacy in the field of road safety and their psychometric properties.

\begin{tabular}{|c|c|c|c|c|}
\hline $\begin{array}{c}\text { Object of } \\
\text { legitimacy } \\
\text { measured }\end{array}$ & Concept operationalizing legitimacy & Reference & $\begin{array}{l}\text { Number } \\
\text { of items }\end{array}$ & Internal consistency \\
\hline \multirow[t]{5}{*}{ Traffic rules } & \multirow{3}{*}{$\begin{array}{l}\text { Perceived rationality, adequacy or efficiency of } \\
\text { specific traffic rules }\end{array}$} & Havârneanu \& Goliţă (2010) & 31 & - \\
\hline & & Havârneanu \& Havârneanu (2012) & 6 & $\alpha=.72$ \\
\hline & & Bautista et al. (2015) & 2 & - \\
\hline & $\begin{array}{l}\text { Perceived rationality, adequacy or efficiency of } \\
\text { traffic rules in general }\end{array}$ & Alonso et al. (2017) & 1 & - \\
\hline & $\begin{array}{l}\text { Perception of traffic rules in general as fair / adequate } \\
\text { / excessive / well done }\end{array}$ & Alonso et al. (2017) & 4 & - \\
\hline \multirow{4}{*}{$\begin{array}{l}\text { Traffic } \\
\text { violations }\end{array}$} & \multirow[t]{3}{*}{ Moral judgment of several traffic violations } & Oceja et al. (2001) & 3 & - \\
\hline & & Bradford et al. (2015) & 2 & - \\
\hline & & Bautista et al. (2015) & 2 & - \\
\hline & $\begin{array}{l}\text { Perceived dangerousness and seriousness of several } \\
\text { traffic violations }\end{array}$ & Alonso et al. (2017) & - & - \\
\hline \multirow[t]{7}{*}{ Police } & \multirow[t]{2}{*}{ Obligation to obey the police } & Bradford et al. (2015) & 3 & - \\
\hline & & MacQueen \& Bradford (2015) & - & - \\
\hline & \multirow[t]{2}{*}{ Moral alignment with police } & Bradford et al. (2015) & 3 & - \\
\hline & & MacQueen \& Bradford (2015) & - & - \\
\hline & \multirow[t]{3}{*}{ Police effectiveness } & MacQueen \& Bradford (2015) & - & - \\
\hline & & Bradford et al. (2015) & 6 & - \\
\hline & & Chermack et al. (2001) & 4 & $\alpha=.81$ \\
\hline
\end{tabular}


Procedural justice, trust in the police or fairness

Demir et al. (2018)

Perceived professionalism and courteousness of police officer

Attitude toward past experience with police

Other measure related to police legitimacy

Sanctions and

means of

control

Agreement with several purposes associated with traffic rules

Agreement with different control methods or

penalties and resources used by the police

Effectiveness of fines in preventing road accidents

General laws,

Social conformism

legal

institutions,

legal system

Moral judgment of general functioning of justice

Moral judgment of functioning of traffic justice

Obligation to obey the law and the authorities
Chermak et al. (2001)

Havârneanu \& Goliţă (2010)

MacQueen \& Bradford (2015)

Alonso et al. (2017)

Watling et al. (2012)

Pérez et al. (2002)

Havârneanu \& Havârneanu (2012)

Alonso et al. (2017)

Alonso et al. (2017)

Bautista et al. (2015)
Procedural justice perception: $\alpha=.87$;

Perception of traffic police legitimacy: $\alpha=$ 86

Perception of police legitimacy generally: $\alpha=$ .89

$r=.67$

Drunk-driving items: $\alpha=.72$;

Speeding items: $\alpha=.91$;

Fatigued driving items: $\alpha=.77$

Driving without seatbelt items: $\alpha=.81$

Respect for the law: $\alpha=.47$

Social order acceptance: $\alpha=.50$

Note.

$\alpha=$ Cronbach Alpha; $r=$ Pearson correlation coefficient

For the number of items and the internal consistency, empty cells signify that the information was not reported in the study concerned. 


\subsubsection{Does legitimacy predict compliance in the field of road safety?}

Of the twenty-six selected publications, six have empirically examined statistical relationships between variables related to legitimacy or rule perception and compliance with traffic rules. One of these studies is based on a longitudinal design while others are based on a cross-sectional design. However, all studies rely on self-declared behaviours. Yet, given the heterogeneity of the measures of legitimacy and compliance, it does not seem relevant to report the sizes of the effects observed in the studies nor to propose a meta-analysis. Statistical significance threshold considered for examining relationships between variables was set at $\alpha=$ .05. Main results are summarized in Figure 3.

Moral judgment, which, as we mentioned, has been used as a way to operationalize legitimacy, was tested by three studies (Bautista et al., 2015; Havârneanu \& Havârneanu, 2012), including the longitudinal study (Lanza-Kaduce, 1988), regarding its effect on compliance. In these studies, moral judgment referred to how badly respondents perceived traffic violations. A positive association between moral judgement about speeding and compliance with speed limits was consistently found in the three studies. As for moral judgment about drunk driving, it was positively associated with past compliance with drink and driving limits in one of the crosssectional studies (Bautista et al., 2005). However, this relationship was not significant in LanzaKaduce's study (1988) which calls into question the possible predictive link between legitimacy - through moral judgement - and compliance regarding this specific law. In addition, moral judgment about running a red light appears to predict compliance with stopping at a red light (Bradford et al., 2015). As for other concepts used in order to operationalize legitimacy, such as rationality, adequacy or efficiency of traffic rules, no significant relationship with compliance was found (Bautista et al., 2015; Havârneanu \& Havârneanu, 2012).

The perceived legitimacy of traffic rules enforcement was positively associated with compliance with rules associated with drunk driving, speeding, and driving while fatigued, but 
not with driving without a seatbelt (Watling \& Leal, 2012). The general appreciation of past experience with the police was positively associated with a measure of compliance in relation to several traffic rules in Havârneanu and Goliţă (2010). The measure of perceived police legitimacy in Bradford et al. (2015), which combines the obligation to obey the police and perceived moral alignment between oneself and the police, was not associated with anticipated compliance with speed and blood alcohol limits. The authors also found a positive indirect relationship between perceived procedural justice and compliance with speed limits and stopping at a red light, which was mediated by perceived police legitimacy. No association between support for authorities and compliance was found in Bautista et al. (2015). A personal feeling of respect for the law (a measure similar to the obligation to obey) was associated with compliance with several traffic rules in Havârneanu and Havârneanu (2012). Congruently, the obligation to obey was found to be positively associated with past compliance with speed limits in Bautista et al. (2015). Finally, in Havârneanu and Havârneanu (2012), attitude toward social order (i.e., social order acceptance) was not associated with compliance with traffic rules.

In summary, the selected publications show that the more drivers judge traffic violations as bad, the more they tend to comply with the associated laws. The perceived legitimacy of traffic rule enforcement appears to have a positive effect globally on compliance with the traffic rules. The obligation to obey and similar measures related to a feeling of respect toward laws or authorities present an inconsistent relationship with compliance. Other measures related to police legitimacy such as procedural justice and positive past experience with the police are significantly associated with compliance. Finally, no association between perceived social order legitimacy and compliance was found. 


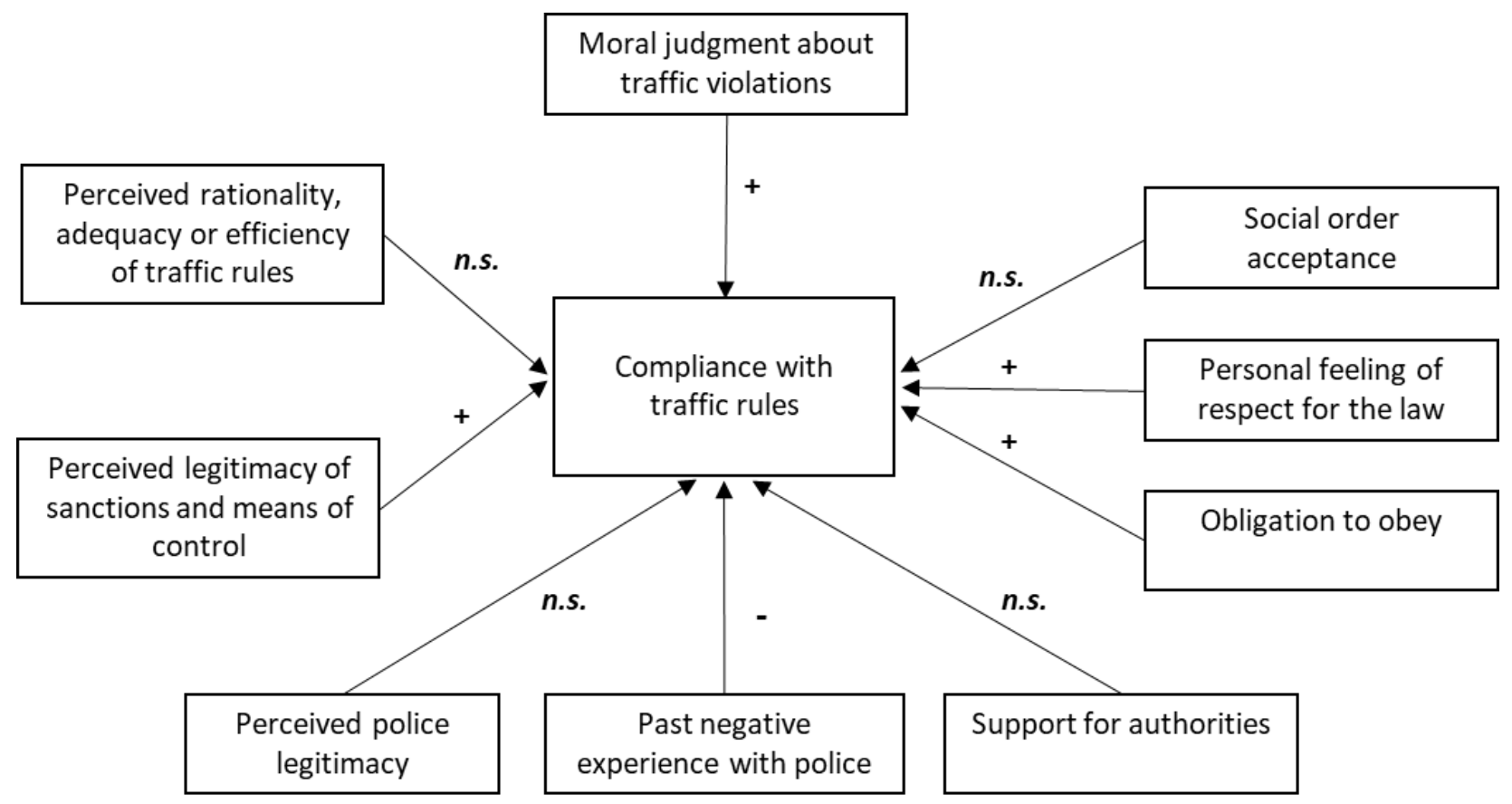

Figure 3. Main empirical relationships identified between measures of legitimacy and compliance in the field of road safety.

Note. n.s.: non-significant statistical relationship. Both objects and concepts operationalizing legitimacy were considered in this summarizing figure (see Table 3 for a distinction between objects and concepts operationalizing legitimacy).

\subsubsection{What are the main determinants and outcomes of legitimacy in the field of traffic rules?}

We identified seven publications that empirically addressed correlates of legitimacy, and thought to be determinants of it. These results are summarized in Figure 4. No studies addressing outcomes of legitimacy beyond compliance (which was treated in the previous section) were identified. All studies rely on self-reported measures and cross-sectional design and do not make it possible to establish causality directions for the investigated relationships, although they were assumed.

The perceived legitimacy of traffic rules was found to be positively predicted by accident involvement and by risk perception associated with traffic violation. Indeed, 
Havârneanu and Havârneanu (2012) found a positive correlation between the perceived rationality of traffic rules and the perceived risk associated with violating these rules. Alonso et al. (2017) found a positive correlation between the perceived effectiveness of traffic rules and involvement in an accident. The perceived legitimacy of traffic violations appears to be negatively predicted by identification with a group sharing social norms of law compliance. Bradford et al. (2015) found that social identification with law-abiding citizens of the country positively predicted moral judgment about traffic violations (i.e., how violations are perceived as wrong) and also with perceived police legitimacy (i.e., the moral obligation to obey the police and perceived moral alignment between oneself and the police). Therefore, perceived police legitimacy appears to be also positively predicted by identification with a group sharing social norms of law compliance. Moreover, perceived police legitimacy was found to be positively predicted by age and negatively by having previous negative experience with the police, particularly being ticketed (Demir et al., 2018; Gau, 2012). For example, Gau (2012) found that procedural justice associated with the police was negatively predicted by having experienced a vehicle search, being previously ticketed by police, arrested by police, and being confronted with the use of force from the police. The perceived legitimacy of sanctions and means of control appears to be positively predicted by age and negatively by attitudes toward traffic violations (Watling, 2019; Watling \& Leal, 2012). For example, Watling and Leal (2012) found that the perceived legitimacy of different enforcement practices was negatively correlated with attitudes toward the corresponding traffic violations. Finally, Havârneanu and Havârneanu (2012) found that respect for the law (i.e., a personal feeling of having to respect laws in general), and social order acceptance (i.e., attitudes towards social order) were positively predicted by risk perception associated with traffic violations. Also, respect for the law was positively predicted by age. This suggests that the legitimacy of general laws, institutions and 
the legal system are negatively predicted by risk perception for traffic violations and positively predicted by age.

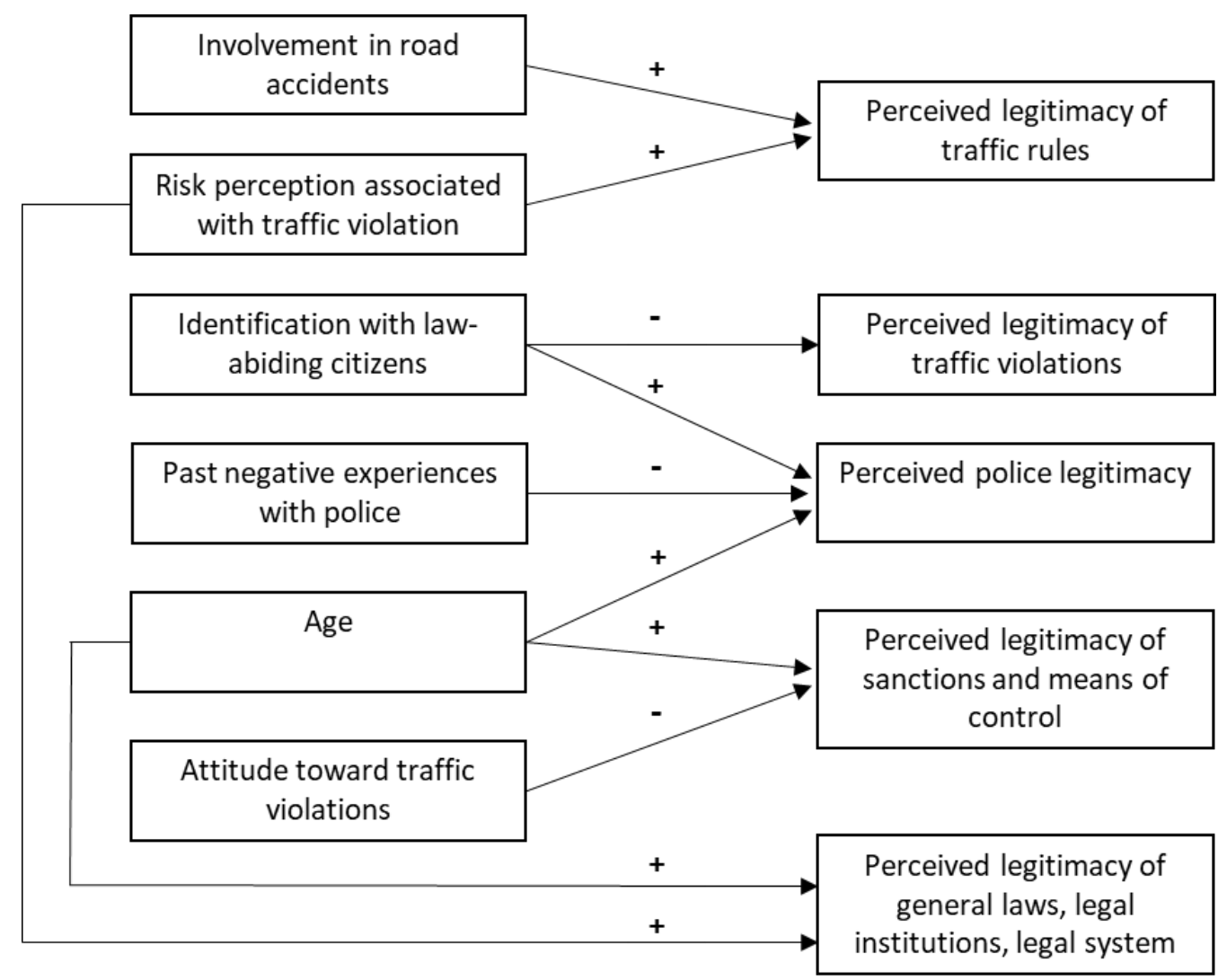

Figure 4. Main empirical relationships identified for hypothesized determinants of the different objects of legitimacy in the field of road safety.

Note. For clarity purpose, only objects and not concepts operationalizing legitimacy were considered in this summarizing figure (see Table 3 for a distinction between objects and concepts operationalizing legitimacy).

\section{Discussion}

The aim of this study was to produce a summary of the knowledge of perceived legitimacy in the road safety field. The analysis of the 26 identified publications showed that the definitions and measures of perceived legitimacy are heterogeneous, and focus on different objects in connection with traffic rules and different dimensions of legitimacy. As definitions 
and measures of perceived legitimacy are highly interrelated, we propose as a first step to discuss these two aspects jointly. More precisely, we emphasize that definitions and measures of perceived legitimacy can apply to different objects or levels and that it is important to distinguish between them more clearly. We also discuss the heterogeneity in definitions of perceived legitimacy and thus propose a basis for developing a multidimensional theoretical model of perceived traffic rule legitimacy. In a second step, we discuss the results of studies that have investigated the link between legitimacy and traffic rule compliance and their implications. In a third step, we discuss the results of studies that have investigated the determinants of legitimacy and the resulting research perspectives. Finally, limitations of our scoping review will be stated before a general conclusion.

\subsection{Issues related to the definition and measurement of legitimacy in the field of road} safety

\subsubsection{Legitimacy can relate to different objects or levels of a given object}

It is important to emphasize that legitimacy can be attributed to different objects such as traffic rules, traffic violations, police and authorities, enforcement means, penalties, justice institutions, laws in general and social order (for a similar observation about police legitimacy see Jackson \& Gau, 2015, see also Jackson 2018). In the field of traffic rules, these objects can be summarized and grouped into three main levels of perceived legitimacy (see Table 4).

Table 4.

Main levels of perceived legitimacy in the field of road safety

\begin{tabular}{cll}
\hline \multicolumn{1}{c}{ Level of legitimacy } & \multicolumn{1}{c}{ Definition } & \multicolumn{1}{c}{$\begin{array}{c}\text { Examples of objects of } \\
\text { legitimacy }\end{array}$} \\
\hline Institutional legitimacy & $\begin{array}{l}\text { Perceived legitimacy of institutions } \\
\text { that create or modify traffic rules and } \\
\text { determine the procedures } \\
\text { (control/penalty) to enforce them. }\end{array}$ & $\begin{array}{l}\text { - Social order and system } \\
\text { - Governmental and } \\
\text { legislative institutions }\end{array}$ \\
\hline
\end{tabular}




\begin{tabular}{|c|c|c|}
\hline Enforcement legitimacy & $\begin{array}{l}\text { Perceived legitimacy concerning the } \\
\text { enforcement procedures and their } \\
\text { actual implementation. }\end{array}$ & $\begin{array}{l}\text { - Enforcement means } \\
\text { - Penalties } \\
\text { - Legal procedures } \\
\text { - Police }\end{array}$ \\
\hline Traffic rule legitimacy & $\begin{array}{l}\text { Perceived legitimacy regarding } \\
\text { obligations or prohibitions imposed } \\
\text { by traffic rules. }\end{array}$ & $\begin{array}{l}\text { - Traffic rules as a whole } \\
\text { - Specific traffic rules }\end{array}$ \\
\hline
\end{tabular}

Thus, legitimacy should be considered as a relative concept in that it describes an attribute or a property that an individual associates with a defined object. Beyond road safety research, measures of legitimacy do not always distinguish these objects of legitimacy. For example, in Tyler et al. (2015), legitimacy was measured with a single-index that included moral alignment with the law, moral alignment with the police, and obligation to obey the police. In Penner et al. (2014), legitimacy combines measures of obligation to obey the law and support for the police and the courts. However, we argue that a clear distinction between objects of legitimacy could be used in order to improve its definition and measurements. For example, legal legitimacy (i.e., legitimacy of laws in general) and police legitimacy are identified as related but distinct objects of legitimacy by Jackson (2018). Moreover, feeling the obligation to obey traffic rules may be distinct from feeling the obligation to obey traffic police, as drivers could agree with the content of traffic rules but not with the way a traffic police officer enforces these rules. In this case, the obligation to obey refers to a particular dimension of legitimacy while traffic rules and police officers refer to a particular object of legitimacy.

The results of the selected articles show that compliance with traffic rules can be explained by the perceived legitimacy of different objects. Therefore, it would be important for future research to determine whether some objects of legitimacy explain compliance with traffic rules more than others. Investigating possible mediational or interactive relationships between different objects of legitimacy on explaining compliance with traffic rules would also be important. Indeed, it may be possible that the effects on compliance of the perceived legitimacy 
of some objects are mediated or moderated by the effect of the perceived legitimacy of other objects. For instance, the perceived legitimacy of a given institution or authority may favor the perceived legitimacy of the laws it enacts. Empirical evidence supports the idea that legitimacy associated with legal authorities and institutions can outweigh legitimacy associated with other objects of legitimacy on shaping compliance. Oceja et al. (2001) found that the legitimacy of traffic rules predicts more compliance for drivers with low levels of conventionalism (i.e., a tendency to respect the law, beyond all ethical considerations) than for drivers with a high level of conventionalism. This suggests that a high perceived legitimacy of the legal system (i.e., the laws of a country in general) could motivate drivers to voluntarily comply with traffic rules independently of the legitimacy they associated with these traffic rules. Beyond road safety, Tyler (2006) reports several findings showing that when legal authorities are perceived as legitimate, people are more willing to perceive procedures dispensed by these authorities and their outcomes as being fair. In other words, the legitimacy of authorities can influence perceived procedural and distributive justice, in turn influencing compliance. Several research findings also suggest that when an authority is perceived as legitimate, people may voluntarily comply with injunctions even when they conflict with their personal values (Milgram, 1974; Tyler, 2006). Thus, better identifying relationships between the different objects of legitimacy and their joint effect on compliance would allow us to identify the main levers of legitimacy on which to act in order to increase compliance with traffic rules.

\subsubsection{Heterogeneity and variability in definitions and measures of legitimacy}

The thematic analysis of selected publications shows that legitimacy in the field of road safety can endorse different definitions, which can be more or less heterogeneous and extensive. The same observation seems to emerge more broadly from the literature on legitimacy in social sciences and outside of the field of road safety research (for a similar critique about police legitimacy see Jackson \& Gau, 2015; see also Hough et al., 2013). We note that examining the 
measurement of legitimacy in the selected publications also added to the concepts mobilized in order to define it. Differences, heterogeneity, and expansivity in the way in which legitimacy is defined in the field of road safety could reflect the diversity of disciplinary fields - and therefore the diversity of theoretical frameworks - that have investigated this object and that we have identified. However, this diversity also appears in studies in the same fields (Jackson, 2018). Thus, legitimacy does not seem to be the subject of a consensual and well-delineated definition, even in a given disciplinary field such as psychology and criminology (for similar critiques see Oceja et al., 2001; see also Jackson \& Gau, 2015). This point presents a serious limitation in considering legitimacy as a psychological construct in itself, and thus the way legitimacy can be investigated, measured and manipulated.

In order to propose a more delineated and consensual definition of legitimacy, it would be important to know to what extent different elements identified in selected publications and overlapping the definition of legitimacy would be its components or rather distinct constructs (i.e., determinants or outcomes of legitimacy). This question could particularly concern elements such as perceived procedural justice, fairness, trustiness, appropriateness, effectiveness, obligation to obey and moral alignment (see Jackson \& Gau, 2015). Legitimacy sometimes appears to be more or less clearly defined through these elements, and sometimes even reduced to them (for an example of the definition of legitimacy including procedural, distributive justice, and perceived effectiveness, beyond road safety, see Tankebe, 2013). However, these elements are also defined in other selected publications as concepts distinct from legitimacy, and their expected causal relationships are sometimes specified (e.g., Bradford et al., 2015; MacQueen \& Bradford, 2015). Moreover, none of the selected studies were based on an empirically corroborated - or have proposed to test an empirical - multidimensional model of legitimacy that accounts for a large part of the different aspects of the construct that could be identified. Only one study in the selection has investigated the dimensional structure of 
measures related to legitimacy through exploratory factor analysis, but was focused only on aspects of police legitimacy (Demir et al., 2018). A lack of theoretical consensus and empirical support in the definition of several elements as being part of legitimacy or as being a rather distinct construct is problematic because it limits the construct and nomological validity of legitimacy and closely related concepts.

The heterogeneity and limitations we underline in defining legitimacy also appear in the measurement of legitimacy and closely related concepts, as shown by our scoping review (see Jackson \& Gau, for a similar critique about police legitimacy; see also Jackson, 2018). Of the twenty-six selected publications, only fourteen include empirical studies using such measurements. Only a few of these were used more than once across these studies, and when this was the case, these measures were often not rigorously validated beforehand. A large part of the measures of legitimacy and closely related concepts more often appear to be proposed and created by authors for the purpose of their study, without having been subject to a validation procedure, and they are not often reused by other authors. When the validity of the measure is assessed, it is most often limited in checking its internal reliability through a Cronbach alpha. We did not identify any studies other than Demir et al. (2018) providing an exploratory factor analysis of the dimensionality of tools, nor having examined the convergent and discriminant validity of tools, as well as test-rest reliability. A lack of consensus in the operationalization of legitimacy and lack of empirical validation of measurement also serves to limit its construct and nomological validity.

\subsubsection{Toward a multidimensional model of perceived traffic rule legitimacy}

Based on the definitions and measures identified in the selected publications, we propose to (re)define the perceived legitimacy of traffic rules as a propriety that individuals associate with a given traffic rule which promotes acceptance of its implementation, enforcement, and motivates individuals to respect the prescriptions that result from it. As 
highlighted, this definition could be improved by considering that legitimacy includes different dimensions, and thus could be based on a multidimensional model. In this way, Hough et al. (2013) have proposed a tripartite model where perceived legitimacy results from three components which are the obligation to obey, moral alignment and perceived legality. This model was also used by Van Damme and Pauwels (2016) to investigate the perceived legitimacy of traffic police.

Legality refers to the perception that the object of legitimacy is based on a sound legal framework. For authorities, legality refers to the perception that they are acting in accordance with legal standards and that their decisions are impartial and objective. Transposed to traffic rules this model could address the obligation to obey traffic rules, moral alignment with values associated with traffic rules, and their perceived legality. However, we argue that considering the obligation to obey as a dimension defining the legitimacy of traffic rules or other objects more broadly could present some theoretical limitations. Indeed, to the extent that legitimacy should imply voluntary compliance with rules as a consequence, the obligation to voluntarily comply with rules would be considered as an outcome of perceiving legitimacy and not as a dimension defining it. Consequently, defining legitimacy by mobilizing the obligation to obey would be tautological. Transposing the legality of traffic police to traffic rules may also appear to be somewhat problematic, as in the first case it refers to measuring to what extent the respondent perceives the actions and decisions of police officers as being firmly based on and in compliance with the law. Following this approach, the legality of traffic rules would refer to the extent to which they are perceived as being compliant with other traffic rules and other nontraffic-related laws. However, this should be often the case for road users, so this should not be a particular dimension of perceived traffic rule legitimacy. Finally, we argue that only the dimension of moral alignment of the tripartite model of police legitimacy (Hough et al., 2013) could be a relevant dimension for inclusion in a model of traffic rule legitimacy. 
Identified definitions and measures of the selected publications, as well as the theoretical reflections that they give to rise to suggest we may consider effectiveness, efficiency and fairness as possible dimensions of traffic rule legitimacy. Acceptability was not explicitly defined in the selected publications. Beyond these publications, Wolfe et al. (2002) propose that an object is judged as acceptable when it is perceived, by the individual, as a relevant means of achieving values that are important for the individual. Therefore, the definition of acceptability seems to overlap with the definition of moral alignment (i.e., a congruent relationship between the values of the individual and the values s/he associated with the object) which already appears as a possible dimension of traffic rule legitimacy. The effectiveness of traffic rules refers to their perceived ability to fulfil their road safety objective properly. In this way, effectiveness also includes the identified definitions and measures of legitimacy related to perceived rationality and appropriateness as they also tap into the perceived ability of traffic rules to fulfil safety objectives that drivers consider to be relevant. In addition, to the extent that the notion of effectiveness might seem too broad, we suggest that it could be differentiated from that of efficiency. While effectiveness would refer to the appreciation that a rule is well adapted to fulfill its purpose, efficiency would refer to the appreciation that the injunctions emanating from the rules are sufficiently proportionate, neither too low nor too high, to achieve the associated objective. We argue that the perceived fairness of the actions and decisions of police officers, which often refers to procedural and distributive justice in selected publications, could be transposed to traffic rule legitimacy. Indeed, people could perceive some traffic rules as applying more or less to all road users, or as being intended to favor or further constrain certain road users or groups of road users. Finally, these theoretical propositions seem to be consistent with Tyler's definition of legitimacy as "a psychological property of an authority, institution, or social arrangement that leads those connected to it to believe that it is appropriate, proper, 
and just" (2006, p. 375), insofar that appropriateness, properness and justness would respectively refer to effectiveness, efficiency and fairness.

In summary, we suggest that traffic rule legitimacy could be based at least on four main dimensions which are moral alignment, effectiveness, efficiency and fairness associated with traffic rules. Because of legitimacy, people feel that they ought to defer to decisions and rules, following them voluntarily out of obligation rather than out of fear of punishment or anticipation of reward. This proposal could serve as a basis for further developing a multidimensional model and measure of perceived traffic rule legitimacy.

\subsection{Does legitimacy predict compliance in the field of road safety?}

Identified results in selected studies suggest that moral judgment about traffic violations generally predict compliance with the associated rule. The more drivers perceive a traffic violation as being wrong, the more they declare that they comply with the corresponding traffic rule. However, this relationship could be moderated by the type of traffic rules concerned, as it was not significant for all traffic rules. It is possible that perceived legitimacy explains violations resulting from deliberate behaviours and not violations resulting from unintentional driver errors. This should be explored in more detail in future studies. A favorable perception of enforcement means is also positively associated with compliance. However, this observation needs to be further corroborated as it was investigated by only one study (Watling \& Leal, 2012). Variables related to perceived rationality, efficiency and adequacy (that are measured similarly) were not found to be significantly associated with compliance in two studies. However, outside of our selected publications, another study on perverse norms found a positive association between the perceived rationality of traffic rules and compliance (Havârneanu \& Havârneanu, 2012). Thus, the role of perceived rationality in shaping compliance needs to be further investigated. 
Measures related to perceived police legitimacy such as procedural justice and positive past experience with the police are positively associated with compliance, while associations between compliance and obligation to obey or similar measures related to sense of respect for the law and authorities are mitigated. These inconsistencies could be explained by the variability of scale content used to measure these two aspects of police legitimacy or traffic rule compliance, as this relationship is strongly corroborated in fields other than traffic (Walters \& Bolger, 2019). The only variable identified regarding general attitude toward laws was found to be positively related to compliance with various road rules (Havârneanu \& Havârneanu, 2012). This suggests that the general representation of laws, beyond solely traffic rules, could influence the representation of specific traffic rules. Finally, attitude toward social order was not found to be associated with traffic rule compliance. This challenges the question of whether general attitudes toward the political and social systems could influence more specific attitudes toward traffic rules. Further research would be needed to confirm or reject this.

More broadly, our scoping review shows that few empirical studies have directly tested the relationship between variables related to legitimacy and compliance with traffic rules (six out of the twenty-six selected publications). Currently, the heterogeneity of the measures used for these variables makes it difficult to compare the results of studies and to perform a metaanalysis to estimate an average effect size. Moreover, all of these studies rely on cross-sectional design, except one, and all rely on self-declared behaviours. Thus, this does not allow us to precisely estimate how legitimacy truly influences effective compliance with traffic rules (which refers to the external validity of legitimacy). This is a crucial point that needs to be investigated in order to develop applied perspectives for road safety. Otherwise, cross-sectional designs do not allow us to establish the direction of causality between legitimacy and compliance. Causality needs to be investigated as perceived legitimacy could be the outcome of a process of rationalization, determined by compliance or violation of traffic rules. In other 
words, drivers who often violate traffic rules could increase their perception of traffic rules as illegitimate in order to maintain a congruent relationship between their attitudes and behaviours and avoid or reduce cognitive dissonance. Conversely, drivers that often comply with traffic rules could increase their perception of traffic rules as legitimate, following the same motivation (Proudfoot \& Kay, 2014; Watling \& Leal, 2012).

Importantly, we identify three experimental studies which tested procedures designed to increase perceived police legitimacy on the road (Bradford et al., 2015; Demir et al., 2018; MacQueen \& Bradford, 2015). The procedure used by Demir et al. (2018) was found to be efficient. The procedure used by Bradford et al. (2015) was also found to be efficient but not in MacQueen and Bradford (2015), which was an attempt to replicate the former contribution cited here. Thus, further research in implementing means of action on perceived police legitimacy, but also on other objects of legitimacy on the road, need to be proposed. This appears an important point for further development as their study could allow causal assumptions between variables to be tested and the trialing of interventions focused on road safety which could be deployed on a larger scale.

Finally, we recommend addressing identified gaps in the investigation of the relationship between perceived legitimacy and traffic rule compliance through further research based on: (a) a robust and validated multidimensional model and measures of legitimacy that allow studies to be compared, (b) experimental and longitudinal designs to test the direction of causality between legitimacy and compliance and to test the effectiveness of road safety interventions, (c) behavioral measures of compliance which test external validity and the actual effects of legitimacy on compliance.

\subsection{What are the main determinants and outcomes of legitimacy in the field of road safety?}

Involvement in accidents was found to be associated with greater perceived legitimacy 
of traffic rules in two studies. Having experienced a traffic accident could make the driver more aware of the risk associated with violations, and therefore of the importance of complying with traffic rules. However, several studies found that accident involvement is associated with a decreased perception of risk while these results are sometimes mitigated, and some other studies found that accident involvement is not associated with effective risk-taking. Moreover, the effect of accident involvement on risk perception could be nonlinear as a function of the characteristics of the accident (Ngueutsa \& Kouabenan, 2017). Therefore, further research should investigate more closely how traffic accident history could affect perceived traffic rule legitimacy. Risk perception associated with traffic violations was found to be positively associated with the perceived rationality of traffic rules. This suggests that the more drivers perceive traffic violations as risky, the more they perceive laws prohibiting them as legitimate. Moreover, identified results also suggest that this effect could be generalized to the perceived legitimacy of the social order.

Interestingly, the study of Bradford et al. (2015) introduces an approach of legitimacy based on the social identity theory (Tajfel \& Turner, 1979). Indeed, the authors found that sharing norms of general law compliance with a social group would lead to greater compliance with traffic rules. Further investigating perceived legitimacy from a social identity and selfcategorization approach (Tajfel \& Turner, 1979; Turner et al., 1987) could be interesting, as taking into account self-categorization and social identification with different groups allows us to predict the effects of social norms on behaviours, such as compliance with traffic rules (Elliott, 2010; see also Tunnicliff et al., 2012). Moreover, recent studies suggest that the dispositional characteristics of road users but also contextual factors on the road can influence self-categorization and social identification processes (King et al., 2012; Tekeş et al., 2019). A better understanding of how these processes are related to legitimacy on the road could offer 
interesting perspectives for road safety.

A negative past experience with the police such as having been arrested, ticketed, and confronted with the use of force, is associated with lower perceived police legitimacy. These results are in line with the broader literature on police legitimacy showing that positive past experience with the police positively predicts compliance (e.g., Jackson, Bradford, Stanko, et al., 2012; Sunshine \& Tyler, 2003). Finally, identified results show that age is positively related to perceived legitimacy for the police, punishment and traffic rule enforcement. This is consistent with the literature showing that, compared to older drivers, young drivers take more risks on the road, have a more positive attitude toward traffic violations and a more negative attitude toward traffic rule enforcement (e.g., Akaateba \& Amoh-Gyimah, 2013; Nordfjærn et al., 2010; Starkey \& Isler, 2016). In this context, perceived legitimacy could be characterized by a mediating role which should be further investigated.

Finally, few empirical studies have investigated the determinants of perceived legitimacy in the field of road safety and all rely on a cross-sectional design that does not allow causality assumptions to be tested. Also, to our knowledge, no study has explored the effects of perceived legitimacy beyond compliance. Thus, experimental or longitudinal studies should be proposed in order to fill in these gaps.

\subsection{Limitations}

This scoping review has several limitations that should be acknowledged. Classical selection bias in scoping review methodology (Sucharew \& Macaluso, 2019) could have operated at several levels. Only publications in English, French and Spanish were considered and we did not take into account research published in other languages, for example in Africa or Asia. Despite the diversity of the databases and keywords used, some studies well suited to our scope could not have been identified. Indeed, the adoption of an exhaustive strategy was not possible because of the limitations of the advanced research features of several databases. 
In particular, grey literature was not checked. The publication selection steps based on authors' evaluations could also involve subjective bias, despite decision criteria being based on shared agreement. Also, scoping reviews do not formally evaluate the quality of evidence, particularly for empirical associations between variables (Sucharew \& Macaluso, 2019). However, in the selected publications, the heterogeneity of measures and the low number of studies investigating associations between the same constructs did not allow us to do so.

\section{Conclusion}

Our scoping review was structured around four main research questions that were: (a) What are the main theoretical definitions of legitimacy in the field of road safety? (b) What are the main measures proposed to address legitimacy in the field of road safety? (c) Does legitimacy predict compliance in the field of road safety? (d) What are the main determinants and outcomes (beyond compliance) of legitimacy in the field of road safety? A comprehensive examination of the selected literature points out the importance of more delineate objects in the field of road safety for which perceived legitimacy is investigated. The identified lack of convergence in the definition and measures of perceived legitimacy calls for further theoretical and empirical development of a multidimensional model and scale for the perceived legitimacy of traffic rules. In this vein, we propose effectiveness, efficiency, fairness and moral alignment as possible theoretical dimensions of a perceived legitimacy model for traffic rules. The identified research indicates that, overall, perceived legitimacy on the road is clearly associated with compliance, but studies currently available are not comparable enough to assess the size of this relationship and causality should be confirmed by experimental or longitudinal studies. Also, identified determinants of legitimacy should be more systematically investigated by future research as they could be interesting levers for acting on perceived legitimacy and increasing compliance with traffic rules and thus decreasing road accidents. Finally, the further development of a federative framework for defining and measuring the perceived legitimacy of 
traffic rules appears to be a prerequisite for producing further comparable studies on the determinants and effects of legitimacy, in order to verify the predictive power of legitimacy over compliance, evaluate the quality of evidence, and thus guide concrete actions in the field of road safety.

Acknowledgements: The authors would like to thank Hélène Batisse for her important involvement in the reference search process.

\section{Declaration of interest: none}

Funding: This work was completed as part of the Catholic University of Lille and the Gustave Eiffel University project Relationship to the rule and perceived legitimacy: evaluation of nudges as a lever for compliance and adherence to traffic rules, funded by the French Delegation for Road Safety (Délégation à la Sécurité Routière).

\section{Authors' contribution}

The authors confirm contribution to the paper as follows:

Funding acquisition, study conception and design, data collection, preliminary analysis of results: Granié Marie-Axelle, Carnis Laurent, Martinez Frédéric, Piermattéo Anthony. Formal analysis and interpretation of the results, drafting the manuscript: Varet Florent. Supervision, project administration: Piermattéo Anthony. All authors participated to reviewing and editing the manuscript and approved the final version.

\section{References}

Akaateba, M. A., \& Amoh-Gyimah, R. (2013). Driver attitude towards traffic safety violations and risk taking behaviour in Kumasi: The gender and age dimension. International Journal for Traffic \& Transport Engineering, 3(4), 479-494. https://doi.org/10.7708/ijtte.2013.3(4).10 
Alonso, F., Esteban, C., Montoro, L., Useche, S. A., \& Crowther-Dowey, C. (2017). Knowledge, perceived effectiveness and qualification of traffic rules, police supervision, sanctions and justice. Cogent Social Sciences, 3(1), 1393855. https://doi.org/10.1080/23311886.2017.1393855

Arksey, H., \& O’Malley, L. (2005). Scoping studies: Towards a methodological framework. International Journal of Social Research Methodology, 8(1), 19-32. https://doi.org/10.1080/1364557032000119616

Barraclough, P., af Wåhlberg, A., Freeman, J., Watson, B., \& Watson, A. (2016). Predicting Crashes Using Traffic Offences. A Meta-Analysis that Examines Potential Bias between Self-Report and Archival Data. PLOS ONE, 11(4), e0153390. https://doi.org/10.1371/journal.pone.0153390

Bautista, R., Sitges, E., \& Tirado, S. (2015). Psychosocial Predictors of Compliance with Speed Limits and Alcohol Limits by Spanish Drivers: Modeling Compliance of Traffic Rules. Laws, 4(3), 602-616. https://doi.org/10.3390/laws4030602

Behnood, A., \& Mannering, F. L. (2017). The effects of drug and alcohol consumption on driver injury severities in single-vehicle crashes. Traffic Injury Prevention, 18(5), 456-462. https://doi.org/10.1080/15389588.2016.1262540

Blumstein, A., Cohen, J., \& Nagin, D. (1978). Deterrence and Incapacitation: Estimating the Effects of Criminal Sanctions on Crime Rates. Washington, DC: National Academies Press.

Bottoms, A. E., \& Von Hirsch, A. (2010). The crime preventive impact of penal sanctions. In P. Cane \& H. Kritzer (Eds.), The Oxford handbook of empirical legal research (p. 96-124). Oxford, England: Oxford University Press.

Bradford, B., Hohl, K., Jackson, J., \& MacQueen, S. (2015). Obeying the Rules of the Road: Procedural Justice, Social Identity, and Normative Compliance. Journal of 
Contemporary Criminal Justice, $\quad 31(2), \quad 171-191$. https://doi.org/10.1177/1043986214568833

Briscoe, S. (2004). Raising the bar: Can increased statutory penalties deter drink-drivers? $\begin{array}{llll}\text { Accident Analysis } \quad \& \quad \text { Prevention, } & \text { 36(5), }\end{array}$ https://doi.org/10.1016/j.aap.2003.10.005

Chermak, S., McGarrell, E. F., \& Weiss, A. (2001). Citizens' perceptions of aggressive traffic enforcement strategies. Justice Quarterly, 18(2), 365-391. https://doi.org/10.1080/07418820100094941

Decker, S., Wright, R., \& Logie, R. (1993). Perceptual deterrence among active residential burglars: A research note. Criminology, 31(1), 135-147. https://doi.org/10.1111/j.17459125.1993.tb01125.x

Demir, S., Demir, B., \& Özkan, T. (2018). When do drivers conform? When do they deviate? Transportation Research Part F: Traffic Psychology and Behaviour, 54, 299-310. https://doi.org/10.1016/j.trf.2018.02.021

Elliott, M. A. (2010). Predicting motorcyclists' intentions to speed: Effects of selected cognitions from the theory of planned behaviour, self-identity and social identity. Accident Analysis \& Prevention, 42(2), 718-725. https://doi.org/10.1016/j.aap.2009.10.021

Fernández-Dols, J. M., \& Oceja, L. V. (1994). Efectos cotidianos de las normas perversas en la tolerancia a la corrupción. Revista de Psicología Social, 9(1), 3-12. https://doi.org/10.1174/021347494763591762

Gau, J. M. (2012). Consent Searches as a Threat to Procedural Justice and Police Legitimacy: An Analysis of Consent Requests During Traffic Stops. Criminal Justice Policy Review, 24(6), 759-777. https://doi.org/10.1177/0887403412464547 
Harcourt, B. E. (2001). The Illusion of Order: The False Promise of Broken Windows Policing. Cambridge: Harvard University.

Havârneanu, M. G., \& Goliţă, A. (2010). Traffic norms between safety and perversity. Annals of the “Al. I. Cuza” University, Psychology series, 19(1), 65-82.

Havârneanu, M. G., \& Havârneanu, C. E. (2012). When norms turn perverse: Contextual irrationality vs. rational traffic violations. Transportation Research Part F: Traffic Psychology and Behaviour, 15(2), 144-151. https://doi.org/10.1016/j.trf.2011.12.003

Hinsch, W. (2010). Justice, legitimacy, and constitutional rights. Critical Review of International Social and Political Philosophy, 13(1), 39-54. https://doi.org/10.1080/13698230903326240

Homel, J. (1988). Policing and punishing the drinking driver: A study of specific and general deterrence. Springer-Verlag.

Hough, M., Jackson, J., \& Bradford, B. (2013). Legitimacy, trust and compliance: An empirical test of procedural justice theory using the European Social Survey. In J. Tankebe \& A. Liebling (Eds.), Legitimacy and Criminal Justice: An International Exploration (p. 326-352). Oxford: Oxford University Press.

Hough, M., Jackson, J., Bradford, B., Myhill, A., \& Quinton, P. (2010). Procedural Justice, Trust, and Institutional Legitimacy. Policing: A Journal of Policy and Practice, 4(3), 203-210. https://doi.org/10.1093/police/paq027

Høye, A. (2014). Speed cameras, section control, and kangaroo jumps-a meta-analysis. Accident Analysis \& Prevention, 200-208. https://doi.org/10.1016/j.aap.2014.09.001

Jackson, J. (2018). Norms, Normativity, and the Legitimacy of Justice Institutions: International Perspectives. Annual Review of Law and Social Science, 14(1), 145-165. https://doi.org/10.1146/annurev-lawsocsci-110316-113734 
Jackson, J., Bradford, B., Hough, M., Myhill, A., Quinton, P. K., \& Tyler, T. (2012). Why Do People Comply with the Law? Legitimacy and the Influence of Legal Institutions. British Journal of Criminology, 52(6), 1051-1071. https://doi.org/10.2139/ssrn.1994490

Jackson, J., Bradford, B., Stanko, E. A., \& Hohl, K. (2012). Just Authority? Trust in the Police in England and Wales. SSRN Electronic Journal. https://doi.org/10.2139/ssrn.2034343

Jackson, J., \& Gau, J. M. (2016). Carving Up Concepts? Differentiating Between Trust and Legitimacy in Public Attitudes Towards Legal Authority. In E. Shockley, T. M. S. Neal, L. M. PytlikZillig, \& B. H. Bornstein (Éds.), Interdisciplinary Perspectives on Trust (p. 49-69). Springer International Publishing. https://doi.org/10.1007/978-3-319-22261$5 \_3$

Kelling, G. L., \& Coles, C. M. (1996). Fixing Broken Windows: Restoring Order and Reducing Crime in Our Communities. New York: Touchstone.

Kelman, H. C. (1961). Processes of opinion change. Public Opinion Quarterly, 25, 57-78.

Kergoat, M., Delhomme, P., \& Meyer, T. (2017). Appraisal of speed-enforcement warning messages among young drivers: Influence of automatic versus human speed enforcement in a known or unknown location. Transportation Research Part F: Traffic Psychology and Behaviour, 46, 177-194. https://doi.org/10.1016/j.trf.2017.01.005

King, M. J., Wood, J. M., Lacherez, P. F., \& Marszalek, R. P. (2012). Optimism about safety and group-serving interpretations of safety among pedestrians and cyclists in relation to road use in general and under low light conditions. Accident Analysis \& Prevention, 44(1), 154-159. https://doi.org/10.1016/j.aap.2010.12.003

Lanza-Kaduce, L. (1988). Perceptual deterrence and drinking and driving among college students. Criminology, 26(2), 321-341. https://doi.org/10.1111/j.17459125.1988.tb00844.x 
Lipsey, M. W., \& Cullen, F. T. (2007). The Effectiveness of Correctional Rehabilitation: A Review of Systematic Reviews. Annual Review of Law and Social Science, 3(1), 297-320. https://doi.org/10.1146/annurev.lawsocsci.3.081806.112833

Lucas, A., \& Pérez, J. A. (2003). Traffic accident driver vs metasystem of moral reasoning. New Review of Social Psychology, 3(2), 310-318.

MacQueen, S., \& Bradford, B. (2015). Enhancing public trust and police legitimacy during road traffic encounters: Results from a randomised controlled trial in Scotland. Journal of Experimental Criminology, 11(3), 419-443. https://doi.org/10.1007/s11292-015-92400

McArdle, A., \& Erzen, T. (2001). Zero Tolerance: Quality of Life and the New Police Brutality in New York City. New York: New York Univeristy Press.

McKenna, F. P. (2007). The perceived legitimacy of intervention: A key feature for road safety. Improving traffic safety culture in the United States: The journey forward. Washington, DC: AAA Foundation for Traffic Safety, 165-175.

Milgram, S. (1974). Obedience to authority: An experimental view. Harper \& Row.

Munn, Z., Peters, M. D. J., Stern, C., Tufanaru, C., McArthur, A., \& Aromataris, E. (2018). Systematic review or scoping review? Guidance for authors when choosing between a systematic or scoping review approach. BMC Medical Research Methodology, 18(1), 143. https://doi.org/10.1186/s12874-018-0611-X

Nagin, D. S. (1998). Criminal Deterrence Research at the Outset of the Twenty-First Century. In T. Michael (Éd.), Crime and Justice: A Review of Research (Vol. 23). University of Chicago Press.

Nagin, D. S. (2013). Deterrence in the Twenty-First Century. Crime and Justice, 42(1), 199-263. https://doi.org/10.1086/670398 
Ngueutsa, R., \& Kouabenan, D. R. (2017). Accident history, risk perception and traffic safe $\begin{array}{lll}\text { behaviour. } & \text { Ergonomics, } & \text { 60(9), }\end{array}$ https://doi.org/10.1080/00140139.2016.1259508

Nordfjærn, T., Jørgensen, S. H., \& Rundmo, T. (2010). An investigation of driver attitudes and behaviour in rural and urban areas in Norway. Safety Science, 48(3), 348-356. https://doi.org/10.1016/j.ssci.2009.12.001

Oceja, L. V., Fernández-Dols, J. M., González, A., Jiménez, I., \& Berenguer, J. (2001). ¿Por qué cumplimos las normas? Un análisis psicosocial del concepto de legitimidad. Revista de Psicología Social, 16(1), 21-41. https://doi.org/10.1174/021347401317351189

ONISR, French National Inter-Ministerial Office of Road Safety. (2018). La Sécurité Routière en France. Bilan de l'accidentalité de l'année 2017 [Road Safety in France. Report on the accidentality for the year 2017]. Paris: La Documentation Française. Retrieved from https://www.onisr.securite-routiere.gouv.fr/etat-de-l-insecurite-routiere/bilansannuels-de-la-securite-routiere/bilan-2017-de-la-securite-routiere

Paternoster, R. (2010). How much do we really know about criminal deterrence? Journal of Criminal Law and Criminology, 100(3), 765-824.

Penner, E. K., Viljoen, J. L., Douglas, K. S., \& Roesch, R. (2014). Procedural justice versus risk factors for offending: Predicting recidivism in youth. Law and Human Behavior, 38(3), 225-237. https://doi.org/10.1037/lhb0000055

Pérez, J. A., Lucas, A., Dasi, F., \& Quiamzade, A. (2002). La desobediencia masiva al código de circulación. Normas heterónomas frente a normas inter-individuales. Psicothema, 14(4), 788-794.

Pratt, T. C., Cullen, F. T., Blevins, K. R., Daigle, L. E., \& Madensen, T. D. (2006). The Empirical Status of Deterrence Theory: A Meta-Analysis. In F. T. Cullen, J. P. Wright, 
\& K. R. Blevins (Eds.), Taking Stock (p. 367-395). Routledge. https://doi.org/10.4324/9781315130620-14

Proudfoot, D., \& Kay, A. C. (2014). Reactance or Rationalization? Predicting Public Responses to Government Policy. Policy Insights from the Behavioral and Brain Sciences, 1(1), 256-262. https://doi.org/10.1177/2372732214550489

Reinders, N. J., Branco, A., Wright, K., Fletcher, P. C., \& Bryden, P. J. (2019). Scoping Review: Physical Activity and Social Functioning in Young People With Autism Spectrum Disorder. Frontiers in Psychology, 10, 120. https://doi.org/10.3389/fpsyg.2019.00120

Seidler, Z. E., Rice, S. M., Ogrodniczuk, J. S., Oliffe, J. L., \& Dhillon, H. M. (2018). Engaging Men in Psychological Treatment: A Scoping Review. American Journal of Men's Health, 12(6), 1882-1900. https://doi.org/10.1177/1557988318792157

Shaaban, K. (2017). Assessment of Drivers' Perceptions of Various Police Enforcement Strategies and Associated Penalties and Rewards. Journal of Advanced Transportation, 2017, 1-14. https://doi.org/10.1155/2017/5169176

Stanojević, P., Jovanović, D., \& Lajunen, T. (2013). Influence of traffic enforcement on the attitudes and behavior of drivers. Accident Analysis \& Prevention, 52, 29-38. https://doi.org/10.1016/j.aap.2012.12.019

Starkey, N. J., \& Isler, R. B. (2016). The role of executive function, personality and attitudes to risks in explaining self-reported driving behaviour in adolescent and adult male drivers. Transportation Research Part F: Traffic Psychology and Behaviour, 38, 127-136. https://doi.org/10.1016/j.trf.2016.01.013

Sucharew, H., \& Macaluso, M. (2019). Methods for Research Evidence Synthesis: The Scoping Review Approach. Journal of Hospital Medicine, 14(7), 416. https://doi.org/10.12788/jhm.3248 
Sunshine, J., \& Tyler, T. R. (2003). The Role of Procedural Justice and Legitimacy in Shaping Public Support for Policing. Law \& Society Review, 37(3), 513-548. https://doi.org/10.1111/1540-5893.3703002

Tajfel, H., \& Turner, J. C. (1979). An integrative theory of intergroup conflict. In S. Worchel \& W. Austin (Eds.), The social psychology of intergroup relations (p. 33-48). Brooks/Cole.

Tankebe, Justice. (2013). Viewing Things Differently: The Dimensions of Public Perceptions of Police Legitimacy: Public Perceptions of Police Legitimacy. Criminology, 51(1), 103-135. https://doi.org/10.1111/j.1745-9125.2012.00291.x

Taylor, M. C., Lynam, D. A., \& Baruya, A. (2000). The effects of driver's speed on the frequency of road accidents. [TRL Report 421]. Transport Research Laboratory.

Tekeş, B., Erkuş, U., \& Lajunen, T. (2019). Does the group membership shape evaluations on other drivers? The role of symbolic cues in traffic. Transportation Research Part F: Traffic Psychology and Behaviour, 63, 216-225. https://doi.org/10.1016/j.trf.2019.04.016

Tittle, C. R. (1980). Sanctions and social deviance: The question of deterrence. New York: Praeger.

Tunnicliff, D. J., Watson, B. C., White, K. M., Hyde, M. K., Schonfeld, C. C., \& Wishart, D. E. (2012). Understanding the factors influencing safe and unsafe motorcycle rider intentions. Accident analysis and prevention, 49, 133-141. https://doi.org/10.1016/j.aap.2011.03.012

Turner, J. C., Hogg, M. A., Oakes, P. J., Reicher, S. D., \& Wetherell, M. (1987). Rediscovering the Social Group: A self-categorization Theory. Basil Blackwell.

Tyler, T.R. (1990). Why people obey the law. Yale University Press. 
Tyler, T.R. (2006). Psychological Perspectives on legitimacy and legitimation. Annual Review of Psychology, 57, 375-400. https://doi.org/10.1146/annurev.psych.57.102904.190038

Tyler, T.R. (2009). Legitimacy and criminal justice: The benefits of self-regulation. Ohio State Journal of Criminal Law, 7, 307-359.

Tyler, T.R. (2010). Why People Cooperate: The Role of Social Motivations. Princeton University Press. https://doi.org/10.1515/9781400836666

Tyler, T.R. (2011). Trust and legitimacy: Policing in the USA and Europe. European Journal of Criminology, 8(4), 254-266. https://doi.org/10.1177/1477370811411462

Tyler, T.R., Jackson, J., \& Mentovich, A. (2015). The Consequences of Being an Object of Suspicion: Potential Pitfalls of Proactive Police Contact: Potential Pitfalls of Proactive Police Contact. Journal of Empirical Legal Studies, 12(4), 602-636. https://doi.org/10.1111/jels.12086

Van Damme, A. (2013). The Roots and Routes to Compliance and Citizens' Cooperation with the Belgian Police. European Journal of Policing Studies, 1(1), 40-63.

Van Damme, Anjuli, \& Pauwels, L. (2016). Why are young adults willing to cooperate with the police and comply with traffic laws? Examining the role of attitudes toward the police and law, perceived deterrence and personal morality. International Journal of Law, Crime and Justice, 46, 103-116. https://doi.org/10.1016/j.ijlcj.2016.04.002

van Haperen, W., Riaz, M. S., Daniels, S., Saunier, N., Brijs, T., \& Wets, G. (2019). Observing the observation of (vulnerable) road user behaviour and traffic safety: A scoping review. Accident Analysis \& Prevention, 123, 211-221. https://doi.org/10.1016/j.aap.2018.11.021

Von Hirsch, A., Bottoms, A. E., Burney, E., \& Wikstrom, P. O. (2000). Criminal deterrence and sentence severity. Hart Publishing. 
Walter, L., Broughton, J., \& Knowles, J. (2011). The effects of increased police enforcement along a route in London. Accident Analysis \& Prevention, 43(3), 1219-1227. https://doi.org/10.1016/j.aap.2011.01.003

Walters, G. D., \& Bolger, P. C. (2019). Procedural justice perceptions, legitimacy beliefs, and compliance with the law: A meta-analysis. Journal of Experimental Criminology, 15(3), 341-372. https://doi.org/10.1007/s11292-018-9338-2

Watling, C. N. (2018). Drivers' perceived legitimacy of enforcement practices for sleep-related crashes: What are the associated factors? Journal of Forensic and Legal Medicine, 54, 34-38. https://doi.org/10.1016/j.jflm.2017.12.005

Watling, C. N., \& Leal, N. (2012). Exploring perceived legitimacy of traffic law enforcement. Proceedings of the 2012 Australasian College of Road Safety National Conference, $1-13$.

Winter, J. C. F., \& Dodou, D. (2010). The Driver Behaviour Questionnaire as a predictor of accidents: A meta-analysis. Journal of Safety Research, 41, 463-470. https://doi.org/10.1016/j.jsr.2010.10.007

Wolfe, A. K., Bjornstad, D. J., Russell, M., \& Kerchner, N. D. (2002). A Framework for Analyzing Dialogues over the Acceptability of Controversial Technologies. Science, Technology, \& Human $\quad$ Values, $\quad 27(1), \quad$ 134-159. https://doi.org/10.1177/016224390202700106

World Health Organization (2015). Global status report on road safety. Geneva, Switzerland: $\begin{array}{lll}\text { WHO } & \text { Press. } & \text { Retrieved }\end{array}$ http://www.who.int/violence_injury_prevention/road_safety_status/2015/en/.

Wright, B. R. E., Caspi, A., Moffitt, T. E., \& Paternoster, R. (2004). Does the Perceived Risk of Punishment Deter Criminally Prone Individuals? Rational Choice, Self-Control, and 
Crime. Journal of Research in Crime and Delinquency, 41(2), 180-213. https://doi.org/10.1177/0022427803260263

Yagil, D. (1998). Gender and age-related differences in attitudes toward traffic laws and traffic violations. Transportation Research Part F: Traffic Psychology and Behaviour, 1(2), 123-135. https://doi.org/10.1016/S1369-8478(98)00010-2

Zimring, F. E., \& Hawkins, G. J. (1973). Deterrence: The legal threat in crime control. Chicago: University of Chicago Press. 